1 Geomorphic and geological constraints on the active normal faulting of the Gediz 2 (Alaşehir) Graben, Western Turkey.

3

Kent, E., ${ }^{1}$ Boulton, S. J., ${ }^{1,} *$ Stewart, I. S., ${ }^{1}$ Whittaker, A. C., ${ }^{2} \&$ Alçiçek, M. C. ${ }^{3}$

${ }^{1}$ School of Geography, Earth and Environmental Sciences, Plymouth University, Plymouth, PL4 8AA, UK.

${ }^{2}$ Department of Earth Science and Engineering, Royal School of Mines, Imperial College, London, UK

${ }^{3}$ Department of Geological Engineering, Pamukkale University, Turkey.

* Corresponding author S.J. Boulton sarah.boulton@plymouth.ac.uk

Abstract: The Gediz (Alaşehir) Graben is located in the highly tectonically active and seismogenic region of Western Turkey. Extension due to regional geodynamic controls has resulted in broadly two-phase evolution of the graben; firstly, low-angle normal faulting relating to the exhumation of the Menderes Massif metamorphic core complex took place between 16 - 2.6 Ma. Secondly, high-angle normal faulting initiated $\sim 2 \mathrm{Ma}$ resulting in the formation of the Gediz and other E-W trending grabens in the region. Here we quantify the throw rate along the fault array over the last $2 \mathrm{Ma}$ using structural and geological constraints, along with analysis of topographic relief as a proxy for footwall uplift. We derive, for the first time, time averaged rates of fault motion from $0.4 \mathrm{~mm} / \mathrm{yr}$ to $1.3 \mathrm{~mm} / \mathrm{yr}$ along the strike of the Gediz Graben, with variation in throw-rate associated with the geometry of individual fault strands. Patterns in throw-rate along strike of the graben bounding fault array also suggest that the fault segments have become linked during the last $2 \mathrm{Ma}$, possibly at $0.8-0.7 \mathrm{Ma}$. Furthermore, these data suggest that an earthquake occurring along the graben bounding fault could have a predicted $\mathrm{M}_{\mathrm{w}}$ of up to 6.3 to 7.6.

The Gediz (Alaşehir) Graben is the northernmost graben of a series of East-West trending neotectonic grabens in western Turkey that dissect the Menderes Massif (Fig. 1), a metamorphic core complex, which preserves evidence of multiple phases of regional metamorphism and deformation spanning from the Precambrian to the Eocene (Şengör et al., 
1984; Bozkurt \& Oberhansli, 2001). To the south of the Gediz Graben lie the Küçük Menderes and Büyük Menderes Grabens that collectively with the Gediz Graben form the major active structures of the Western Anatolian Extensional Province (WAEP) (Saunders et al., 1998; ten Veen et al., 2009). Extensional deformation in the WAEP is likely the result of subduction zone roll-back along the Aegean-Cyprian trench (Le Pichon \& Angelier, 1979; Kissel \& Laj, 1988; Meulenkamp et al., 1988; Meulenkamp et al., 1994; Çiftçi \& Bozkurt, 2009a), although orogenic collapse and back-arc extension have also been proposed to explain the exhumation of the Menderes Massif (i.e., Seyitoglu \& Scott, 1996).

Despite the debate as to the underlying geodynamic cause of the regional extension, it is clear that metamorphic core-complex exhumation began during the early Miocene $\sim 20-$ 16 Ma (Sengör, 1987; Dewey, 1988; Meulenkamp et al., 1994; Çiftçi \& Bozkurt, 2009b; 2010; Buscher et al., 2013). Owing to either low-angle, bivergent and symmetrical detachment faulting accommodating the exhumation of the Menderes Massif along regionally extensive detachment surfaces (Ring et al., 2003; Collins \& Robertson, 2003) or to asymmetrical exhumation along the Datça-Kale breakaway fault (Seyitoğlu et al., 2004). Recent work by Buscher et al. (2013) showed that the low-angle detachment faulting in the Gediz Graben continued to be active up until $\sim 2$ Ma and had a slip rate of $4.3(+0.3 /-1.2)$ $\mathrm{mm} / \mathrm{yr}$, supporting the rolling hinge mechanism for the development of the graben (Seyitoğlu \& Sen, 1998; Seyitoğlu et al., 2002; 2004; 2014; Demircioğlu et al., 2010), after which deformation switched to high-angle faulting on basin bounding faults. A view broadly supported by other studies into the two-stage evolution of the graben (e.g., Koçyiğit et al., 1999; Bozkurt \& Sözbilir, 2004; Purvis \& Robertson, 2004; 2005; Oner \& Dilek, 2011) although these works suggest that low-angle detachment faulting had ceased prior to the initiation of high-angle normal faulting.

The present basin is an asymmetrical graben dominated by high-angle faults on the southern margin, which offset the now inactive low-angle detachment fault. The high-angle normal faults have also uplifted Miocene sediments in the footwall and form a topographic break to the modern graben floor (Fig. 2). Although the transition from low-angle to highangle faulting is now constrained at 2.6 - $2 \mathrm{Ma}$, using sedimentological (Purvis \& Robertson, 2004; 2005), stratigraphical (Oner \& Dilek, 2011) and radiometric means (Buscher et al., 2013), the present day slip rate on the Gediz Graben boundary fault (GGBF) is not well constrained. However, the structural and sedimentological studies of Oner and Dilek (2011) combined with the radiometric dating of Buscher et al. (2013) give a possible post earlyPleistocene ( 700 Ka) age for development GGBF (Fig. 2). This suggests that although a 
sedimentary basin was present during the Miocene, the modern graben configuration and much of the graben topography has only developed during the Quaternary.

Furthermore, the Gediz Graben is still tectonically active with a record of recent and historical earthquakes. In $17 \mathrm{AD}$ the Lydia earthquake caused extensive damage to the region and to the city of Sardis, capital of the ancient kingdom of Lydia and close to the modern town of Sart, which sustained damage from which it never truly recovered (Erdoğan, 2014). More recently, large magnitude earthquakes occurred in 1866 (Ambraseys \& Jackson 1998), and a $\mathrm{M}_{\mathrm{w}}=6.9$ earthquake occurred in 1969, creating a surface rupture of around > 30 km (Arpat \& Bingol, 1969; Eyidoğan \& Jackson, 1985). This evidence of destructive earthquakes shows that population centres within the Gediz Graben are at risk from the hazards associated with active faulting, and that it would clearly be advantageous to constrain fault throw-rates along the graben bounding fault. Unfortunately, there are currently no estimates for present-day fault slip rate along the $120 \mathrm{~km}$ extent of the graben, and few constraints on how this fault system has evolved from the Pleistocene to the present day.

Yet the geology of the Gediz Graben is relatively well documented. Previous research has focused on mapping the Miocene to recent continental clastic rock units and constraining the age of deposition through fossil content of the sediments (İztan \& Yazman, 1991; Cohen et al., 1995; Seyitoğlu \& Scott, 1996; Koçyiğit et al., 1999; Sarıca 2000; Purvis \& Robertson, 2005; Ciftci \& Bozkurt, 2009a; Oner \& Dilek, 2011) and magnetostratigraphy (Sen \& Seyitoğlu, 2009). Published structural work has documented the location and orientations of faults and folds (i.e., Ediger et al., 1996; Seyitoğlu \& Scott, 1996; Şan, 1998; Seyitoğlu et al., 2002; Bozkurt, 2003; Çiftçi \& Bozkurt, 2009a; Oner \& Dilek, 2011) while recently-acquired shallow seismic survey data has allowed the subsurface geology to be constrained for the first time (Çiftçi \& Bozkurt, 2010; Demircioğlu et al., 2010; Seyitoğlu et al., 2014).

In this paper, we integrate these previously published datasets with digital elevation model (DEM) data to derive fault throw and slip-rates from geologically well-constrained cross-sections and then extrapolate these data along the strike of the graben using topographic metrics, in order to quantify fault throw-rate across the southern margin of the graben at specific locations along the length of the Gediz Graben for the first time. These new data not only provide critical information on the active tectonics of the Gediz Graben but provide information for future seismic hazard and risk analyses.

\section{GEOLOGICAL BACKGROUND}


Here we synthesise the existing stratigraphic and structural data available on the stratigraphy and structure of the Gediz Graben, with an emphasis on data used for cross-section construction.

\section{Stratigraphic Framework}

Alluvial and fluvial sediments dominate the lithologies within the Gediz Graben, composed of mainly of coarse-grained siliciclastic sediments deposited in the basin and then progressively uplifted in the footwall of the southern basin bounding normal faults. The thickness and lateral extent of the sedimentary units varies along the strike of the graben from west to east with lateral discontinuities either due to primary sedimentary processes or faulting (İztan \& Yazman, 1991; Cohen et al., 1995; Koçyiğit et al., 1999; Sarıca 2000; Seyitoğlu et al., 2002; Purvis \& Robertson, 2005; Çiftçi \& Bozkurt, 2009a; Oner \& Dilek, 2011). Naming conventions for the graben fill sediments have varied in the literature leading to confusion in the past; however, in this study we adopt the framework used by Çiftçi (2007) and Çiftçi and Bozkurt, (2009a) to facilitate the use of the seismic sections interpreted and published by them (Fig. 3). This framework defines five formations that unconformably overly the metamorphic rocks of the Menderes Massif. These are the early Miocene Alaşehir Fm., the middle Miocene Çaltılık Fm., the late Miocene Gediz Fm., and the Pliocene Kaletepe and Bintepeler Fms. Finally, Quaternary alluvium is present in the axis of the graben and travertines are locally present along the boundary fault (Çiftçi \& Bozkurt, 2009a).

The majority of evidence for the age of the sedimentary infill of the graben comes from the fossil content of specific rock units compiled from a number of studies (e.g. Ediger et al., 1998; Seyitoğlu \& Scott, 1996; Y1lmaz et al., 2000). The Alaşehir Formation has been dated by Ediger et al. (1998) as Early to Middle Miocene after palynological investigation identified an Eskihisar sporomorph assemblage (Benda, 1971). This dating was refined by isotopic methodologies, particularly by use of Ar-Ar dating on volcanic rocks, to 20-14 Ma (Richardson-Bunbury, 1996). Additionally, the magnetostratigraphy of Sen and Seyitoğlu (2009) correlated the Alaşehir Formation to the interval C5Cn.3n-C5ADr, between 14.6-16.6 Ma.

The Gediz Formation, which includes the Salihli and Hamamdere Members, had been suggested to be of early-middle Miocene (20-14 Ma) age (Seyitoğlu \& Scott, 1996). However, this finding was rejected by Yilmaz et al. (2000) due to possible reworking of lignite. Yet other independent samples (Ediger et al., 1998; Seyitoğlu et al., 2002; Şen \& 
Seyitoğlu, 2009) provide additional Eskihisar sporomorph association data, throwing doubt upon total reworking. Yeni Eskihisar (14-11 Ma) or Kizılhisar (11-5 Ma) sporomorph associations have been identified within the Calt1l1k and Gediz Formations by Ediger et al. (1998). Y1lmaz et al. (2000) state a preference for the dating of Ediger et al. (1998) who propose a Middle Miocene or Late Miocene age based on Yeni Eskihisar (14-11 Ma) or Kizllhisar (11-5 Ma) sporomorph associations. The Yeni Eskihisar sporomorph association was also recognised by Koçyiğit et al. (1999) within their Göbekli Formation, which is approximately equivalent to the lower part of Gediz Formation defined by Çiftçi and Bozkurt (2009a).

The Gobekli Formation of Koçyiğit et al. (1999) has also been dated using gastropod fauna (Emre, 1996; Purvis \& Robertson, 2005) that yielded an age of Late Miocene (c. 11 Ma.). Consequently, they map the upper Gediz Formation of Çiftçi and Bozkurt (2009b) as the Yenipazar Formation in which plant fragments, pollen, gastropod and rare mammalian fossils were found in the middle sections of the formation, these give Late Pliocene (3 Ma) and younger Pleistocene ages (Sarica, 2000).

There is an unconformity above this unit identified by most workers (Fig. 3) which is likely to be Pleistocene in age. A mid-Pleistocene age for overlying sediments (the Kaletepe Formation and Bintepeler Formation of Çiftçi and Bozkurt (2009a)) is supported by field observations of Cervus elapus and Bos primigenius teeth and jaw bones (c. $800 \mathrm{Ka}$ ) within the units above the Gediz/Yenipazar Formation (Sarica, 2000), although this study considers that the bottom of the Kaletepe Formation (their Asartepe Formation) may be as old as late Pliocene in age.

Considering all of the evidence provided by biostratigraphy and dating methods the Alaşehir Formation has bracketing ages of 20-14 Ma, overlain by the Caltılik and Gediz Formations of 14-3 Ma. These formations are in turn overlain by the youngest sedimentary units, the Kaletepe Formation and Bintepeler Formations, which have a Pliocene to Pleistocene age ranging from 2.6-0.7 Ma. The Quaternary alluvium is juxtaposed against the Kaletepe Formation and Bintepeler Formations by high-angle normal faulting at the graben margin.

\section{Structural Framework}

Previous geological research on the structure of the graben (e.g. Patton, 1992; Cohen et al., 1995; Hetzel et al., 1995; Emre 1996; Koçyiğit et al., 1999, Yılmaz et al.. 2000, Sözbilir, 2001, Sözbilir, 2002; Seyitoğlu et al., 2002; Purvis \& Robertson, 2004; Çiftçi \& Bozkurt, 
2009a; b; 2010; Oner \& Dilek, 2011) document three main styles of faulting within the Gediz Graben (Fig. 2): (i) the main low-angle detachment, (ii) high-angle normal faults, and (iii) low-angle normal faults.

\section{The Gediz Detachment Fault}

The Gediz Graben is bounded along the southern margin by a low-angle detachment fault, a normal fault with a low dip varying between $15^{\circ}-28^{\circ}$ to the north and a general E-W strike (Fig. 2), forming the boundary between the sedimentary graben fill and the metamorphic basement of the Menderes Massif. The detachment has been variably named the Gediz detachment (Lips et al. 2001), the Alaşehir detachment (Iş1k et al., 2003), the Karadut fault (Emre, 1996), the Çamköy detachment (Koçyiğit et al. 1999), the Southern Boundary Fault (Seyitoğlu \& Scott, 1996), and Fault 1 (Seyitoğlu et al., 2002). This detachment is cut by a number of structures orientated at a high angle to the general direction of strike as well as by later high-angle normal faults on the flanks of the margin (e.g., Seyitoğlu et al., 2002; Bozkurt \& Sözbilir, 2004; Purvis \& Robertson, 2004).

Recent dating of the fault by Buscher et al., (2013) and the interpretation of seismic data by Çiftçi and Bozkurt, (2009a) and Demircioğlu et al., (2010) lend support to the model of progressive development of the detachment fault through a rolling hinge mechanism (Seyitoğlu et al., 2002). In this model the detachment fault developed as a high-angle normal fault that has been subsequently rotated, while still active, with younger faults splaying off the detachment fault at depth (Seyitoğlu et al. 2014). Although, models where the later high angle faults cut and displace the detachment fault have not been completely ruled out (Çiftçi \& Bozkurt, 2009a).

\section{Major graben bounding normal faults}

The high-angle normal faults occur as both major faults and as smaller synthetic and antithetic faults to the graben bounding normal faults (Çiftçi \& Bozkurt, 2009a). The main fault arrays generally strike WNW-ESE (Çiftçi \& Bozkurt, 2009a) and have disturbed both the graben sedimentary fill and possibly the metamorphic basement rocks of the Menderes Massif (Koçyiğit et al. 1999) forming the high relief southern margin of the Gediz Graben. When the southern graben is observed in map view, the major high angle normal faults appear to be curvilinear and segmented along the length of the graben (Çiftçi \& Bozkurt, 2007; 2009a). Along most the length of the southern graben margin there are two main highangle fault lineaments (Fig. 2); a fault array separating the Neogene sediments from the 
Quaternary Alluvium in the graben valley, which we will call the Gediz Graben Boundary Fault (GGBF), which correlates with Fault III of Seyitoğlu et al. (2002), and a series of faults located between the GGBF and the Gediz Detachment, which we term the Bozdağ fault system (BFS), equivalent to the MGBF of Çiftçi and Bozkurt (2009a) and Fault II of Seyitoğlu et al. (2002). The GGBF (Fig. 4) is curvi-linear and segmented into three strands (Çiftçi \& Bozkurt, 2007; 2009a): the Turgutlu strand to the west (41 km long), the central Salihli Strand (43 km long) and the Alaşehir segment in the east $(36 \mathrm{~km})$. The GGBF separates the modern graben from the youngest basin fill, the Pleistocene Kaletepe Formation and Bintepeler Formations. Oner and Dilek (2011) also observed offset alluvial fans along the range front, and thus the GGBF constrained to have been initiated since 2- 2.6 Ma (Purvis \& Robertson, 2004; 2005), with a possibility of younger age for dominant faulting being considered by some authors (Oner \& Dilek, 2011; Buscher et al., 2013).

Subsurface data indicate that at depth the GGBF and BFS possibly merge with the Gediz Detachment Fault (Çiftçi, 2007; Çiftçi \& Bozkurt, 2010; Demircioğlu et al., 2010). Furthermore, the $1969 \mathrm{M}_{\mathrm{w}} 6.9$ earthquake had a focal depth of $6 \mathrm{~km}$ and took place on a fault dipping $32^{\circ}$ to the NNE (Eyidoğan \& Jackson, 1985). Although, the GGBF appears to be seismogenic and a clear topographic break is observed at the edge of the present day graben, the fault scarp is not well preserved due to the unconsolidated nature of the footwall sediments (Purvis \& Robertson, 2004).

\section{Other normal faults}

High-angle faults can also be observed cutting the detachment fault on the flanks of the graben. These are smaller than the main fault arrays and have been interpreted either as the youngest Quaternary structures of the graben (Fault IV of Seyitoğlu et al., 2002) or as synthetic or antithetic to the GGBF (i.e., Çiftçi \& Bozkurt, 2009a; Oner \& Dilek, 2011).

Furthermore, Low-angle normal faults can be found in both the sedimentary graben fill and the metamorphic rocks of the Menderes Massif where they appear to have fairly similar dips and orientations to the detachment (Oner \& Dilek, 2011). These low-angle normal faults are best seen within the valleys of rivers flowing from south to north as this exposes cross sectional views and good exposures of the sedimentary units. The faults usually strike to the ENE with dips ranging from $10^{\circ}$ to $25^{\circ}$ to the NNW and seem to be brittle, near surface structures with small amounts of offset (Oner \& Dilek, 2011). The low-angle normal faults occur in the same locations as the high-angle normal faults and display a complex cross 
cutting relationship with both the synthetic and antithetic faults (Çiftçi \& Bozkurt, 2009a; Oner \& Dilek, 2011).

\section{Methodology}

Geophysical (2-D seismic reflection surveys) data (Çiftçi, 2007) were used in conjunction with structural data and field-verified published geological mapping (i.e., Ediger et al., 1996; Seyitoğlu \& Scott, 1996; Şan, 1998; Çiftçi \& Bozkurt, 2009a; 2010; Oner \& Dilek, 2011), data from three boreholes within the modern topographic graben (Çiftçi, 2007), and sediment thickness data (Oner \& Dilek, 2011) to produce six cross-sections combining the surface and sub-surface data across the Alaşehir fault segment in the east of the graben (Figs. $4 \& 5$ ). The boreholes and 2-D seismic reflection surveys were collected during hydrocarbon exploration in the areas around Alaşehir. Seismic lines s4-s16 were shot around the area of Alaşehir close to the location of three boreholes (Fig. 2), which give thicknesses of the sediment packages within the topographic graben through the development of a velocity model (Çiftçi, 2007). The thicknesses and orientation for the sedimentary units outcropping along the graben margin were documented by Oner and Dilek (2011) during field examination. We note that there are some inconsistences between datasets likely due to syn-sedimentary tectonics.

The cross-section method for analysing fault throw rates is a sound technique for quantifying displacement rates over several million years when based upon accurate geologic data (Cowie \& Roberts, 2001; Roberts \& Michetti, 2004). The total throw was measured only on the main graben bounding high-angle normal faults which are continuous along strike using stratigraphic piercing points on the cross-sections, i.e., the BFS and GGBF (Fig. 5; Table 1). The piercing points were the most reliably mapped sedimentary units on each cross-section to give maximum throw values for the $2 \mathrm{Ma}$ of high-angle normal fault activity. Consequently, measurements were made using the base of the Alaşehir, Çaltılık, Gediz and Kaletepe formations where appropriate, as these were the sedimentary units obviously backtilted by the high-angle normal faulting, and most confidently mapped as being present in the footwall and hanging wall of the faults (Fig. 5).

This cross-section analysis gave measurements for the throw on the BFS and the GGBF for the six measured cross-sections; these values were summed to give cumulative total throw across the southern graben margin as a whole. However, this is a conservative estimate of total throw as smaller normal faults have not be included as they are often of 
limited lateral extent. The errors on the throw values (Table 1) were quantified by measuring the possible vertical offset that would enable the units to dip at the documented angle while occupying the same area on a map, and is dependent upon their thicknesses as described in the literature (e.g. İztan \& Yazman, 1990; Ediger et al., 1996; Emre, 1996; Seyitoğlu \& Scott, 1996; Koçyiğit et al., 1999; Çiftçi \& Bozkurt, 2009b; Sen \& Seyitoğlu, 2009; Oner \& Dilek, 2011).

\section{Throw rates along the entire length of the graben bounding faults}

To provide data on the total fault throw along the whole length of the graben bounding range, available DEM imagery combined with structural and stratigraphic mapping data were used in conjunction with the measurements of throw gained from cross-section analysis to expand the dataset to areas without geophysical data. This was achieved through topographic analysis of footwall relief.

A $30 \mathrm{~m}$ ASTER DEM (NASA, 2001) of the southern bounding range of the Gediz Graben was divided up into a series of twenty north-south oriented swaths of $5 \mathrm{~km}$ width (Fig. 4) to generate topographic swath-profiles. The average spacing between rivers along the Bozdağ block is $\sim 4.5 \mathrm{~km}$, so the $5 \mathrm{~km}$ interval was selected to avoid topographic basis due to river systems. The maximum and minimum elevation profiles were then extracted along each swath profile to produce the topographic relief (the difference between the graben floor and the highest elevation) for each of the twenty swath sections (Figs. $4 \& 6$ ). The derived values for relief can then be used to gain information about throw on an adjacent fault (cf., Densmore et al., 2004; Whittaker \& Walker, 2015). Footwall uplift is a component of total throw on a normal fault, which is made up of a combination of footwall uplift and hanging wall subsidence. Therefore, the value of relief is not a direct proxy for total throw on the fault, but in some circumstances can be used as a proxy for the footwall uplift component.

Footwall relief can become decoupled from fault displacement towards the centre of a fault, if an (erosionally-limited) threshold elevation is reached, particularly after the timeintegrated accumulation of large displacement. In this circumstance, topography will continue to record fault displacement variation only at the fault tips (c.f. Densmore et al., 2004; 2007). Nevertheless, a number of studies have demonstrated that footwall relief does reflect along-strike variations in throw and throw rate to first order, for segmented faults in the Northern Apennines (e.g. Mirabella et al., 2004) and the Sperchios Graben of Greece (Whittaker \& Walker, 2015), both of which have been active since the Plio-Pleistocene. Because the Menderes massif has not been substantially glaciated, relief in this area is largely 
controlled by fluvial erosion, which we know may take 1-5 Myrs to achieve a topographic steady state with respect to an imposed uplift field (e.g. Whitaker et al., 2007a, 2007b, Whittaker \& Boulton, 2012). We therefore quantify the variation in footwall relief along the Alaşehir fault segment for which we also have geologic constraints, and we use this to calibrate the extent to which topographic relief in the Gediz Graben reflects along strike variations in fault throw more widely.

An important consideration, given there is a two stage history of graben formation, is to the most appropriate relief to extract via the swath-profile for this investigation. One approach is to extract the total relief, measured to the highest topography within the metamorphic basement rocks; however, this measure of topographic relief may contain a component created by the low-angle fault, over its (earlier) period of activity. The alternative is to effectively divide the graben margin into two areas based upon the dominant style of faulting (Fig. 6) and to consider the hanging wall of the Gediz Detachment only (which is also the proximal footwall of the GGBF). As this is the location of the significant high-angle faulting and syn-tectonic sediment accumulation, the topography in the hanging wall of the Gediz Detachment may better represent and isolate the uplift on the high-angle faults (Fig. 6). Consequently, footwall relief was defined and measured as the highest topography of the sedimentary units back-tilted by high-angle normal faulting in the hanging wall of the Gediz Detachment; errors are determined from the known vertical resolution of the DEM.

The cumulative throw values for the southern graben margin obtained for the six cross-sections (Table 2). The ratio of footwall uplift to hangingwall subsidence, and the ratio of footwall uplift to total throw can then be calculated for each cross-section (c.f. Whittaker $\&$ Walker, 2015). These ratios consistently lay in the range 1:3.0 to $1: 4.8$, with an average value of 1:4.1 (Table 1). Previous research suggests that ratios of footwall uplift to hanging wall subsidence may vary between areas (e.g. Papanikolaou et al., 2010). For example, Papanikolaou et al. (2010) found a 1:3 footwall uplift to hanging wall subsidence ratio in Lazzio-Abruzzo, Italy, using differential SAR Interferometry and GPS recordings from nearby field GPS stations. On the Xylokastro Fault in the Gulf of Corinth ratios of between 1:2.7 and 1:3.5 have been determined using plate models by Armijo et al. (1996). Similar values of 1:3 were found for faults in the Sperchios Graben in central Greece (Whittaker \& Walker, 2015). By contrast, Stein and Barrientos (1985) found that in the Basin and Range province ratios vary between 1:1 and 1:5 over for both coseismic and longer-term motions on a fault. 
Clearly, the ratio for the Gediz Graben falls within the range of previous estimates. If footwall relief were largely controlled by denudational processes, we would expect the ratio of footwall relief to throw to vary considerably along strike, with very high values obtained where cumulative throw is large but topography is erosionally-limited (c.f. Densmore et al., 2004). As our data do not show this relationship, we therefore conclude that footwall relief in the Alaşehir fault segment is recording the variation in fault throw along strike with an acceptable degree of fidelity, and we therefore use this averaged ratio to estimate total throw along the southern margin of the Gediz Graben along strike from our topographic swath profiles in areas where we do not have 2D seismic or borehole data. Error was determined by calculating the difference between the measured throw and cumulative throw at each crosssection location and then taking the average of these values.

\section{Extracting data from areas without 2-D seismic survey data}

The derived footwall relief to total throw ratios were applied to the footwall uplift component derived from the relief analysis for twenty swath sections along the southern bounding range (Table 2), in order to produce a first order estimate of the total throw across the high-angle normal faults for each swath location. This assumes that relief is a good proxy for footwall uplift over the period of high-angle faulting. After throw values were estimated for each swath location, a throw rate was calculated using the published range of values for the duration of high angle faulting, namely 2.6 Myr, 2 Myr and 0.7 Myr to give a time averaged throw rate

To facilitate comparison to other areas where only slip-rate data are available, the derived throw values for the Gediz Graben were also converted to give the slip and slip-rate values on the faults in those swath locations (Table 2). Slip-rate data were measured for the six cross-section locations but a method was required that would give values for each of the 20 locations in a uniform way. Nicol et al. (1997) determined that throw on a fault is, on average, approximately $75 \%$ of the slip on the same fault, which is equivalent to assuming an average fault dip of $~ 50$ degrees; therefore, this value was used to convert throw-rates, as calculated for the last $2 \mathrm{Ma}$, into slip-rate estimates. 


\section{Results}

\section{Throw on the high-angle normal faults}

Using the cross-sections (Fig. 5) the cumulative throw and throw-rates for the southern graben margin were quantified in six locations in the east of the graben (Figs. $4 \&$ 7a; Table 1). Total throw measured on the normal faults ranges from $2000 \mathrm{~m}$ on crosssection $\mathrm{E}$ and $3900 \mathrm{~m}$ on cross-section $\mathrm{C}$, with additional values of $2250 \mathrm{~m}$ on section $\mathrm{A}$, $3600 \mathrm{~m}$ on section B and $2600 \mathrm{~m}$ on section D and $3375 \mathrm{~m}$ on section F. Of this total, the accumulated of throw is approximately equally distributed between the BFS and GGBF (Table 1). The error analysis gives vertical errors of between \pm 100 to $250 \mathrm{~m}$ on the total throw amounts. This is between 4 to $15 \%$ of the total throw measured and when applied is not likely to have a significant impact upon the relative magnitudes of throw along strike.

\section{Footwall uplift values along strike}

The swath analysis method was used in conjunction with constraints calculated from the cross-sections to quantify the time-integrated footwall uplift for the 20 swath locations along the southern graben margin (Fig. 4). Relief of the uplifted syn-tectonic sedimentary units varies from $217 \mathrm{~m}$ to $724 \mathrm{~m}$ with two distinct sections to the range. The eastern $80 \mathrm{~km}$ of the range generally has higher relief, varying between $420 \mathrm{~m}$ and $697 \mathrm{~m}$, while the western $45 \mathrm{~km}$ has the majority of the lower relief with values ranging from $244 \mathrm{~m}$ to $420 \mathrm{~m}$ at the westernmost extent (Figs. 4 and 8). Relief generally increases from west to east with higher uplift values in the central area of the range and towards the eastern extent (Fig. 8). There is a clear relationship between throw (both cumulative and throw on the GGBF) and footwall relief (Fig. 7b), where higher relief correlates to greater throw confirming our assumption that relief can be used as a proxy for throw. When the three active graben-bounding normal fault segments are displayed with footwall uplift values (Fig. 8) there is an overall trend to higher footwall uplift values in the centre of the range within the Salihli Segment with the lowest values on the Turgutlu fault segment. Uplift values fall towards the edges of the fault segments, this is particularly notable where the Salihli fault segment ends and the Alaşehir segment begins, at $80 \mathrm{~km}$ along strike.

In summary, (i) footwall relief varies along strike in a systematic way; (ii) reaches a minimum (but not zero) near the fault segment boundaries, and (iii) is a maximum in the centre of each fault segment. Finally, footwall relief (and throw) is highest along the Salihli (middle) segment of the fault. 


\section{Total throw values along strike}

Estimates for footwall relief and cumulative throw along strike, based on the methods described above are shown in Table 2 and Figure 8. The cumulative throw values calculated from the topographic analysis share the same along strike trends as the footwall uplift; the maximum throw value at the centre of the Salihli fault segment is $\sim 2970 \mathrm{~m}$, with values decreasing to zero at the eastern and western extremes of the range, but not at the locations of fault tips internal to the whole fault array.

The throw values have three peaks, located at approximately the centre of each fault segment with an overall peak within the centre of the fault array. The largest throw value of $2970 \mathrm{~m}$ is found within the central Salihli fault segment around $70 \mathrm{~km}$ along the Bozdag Range, additional segment peaks of $1630 \mathrm{~m}$ for the Turgutlu Segment and $2530 \mathrm{~m}$ for the Alaşehir Segment have been quantified at around mid-way along each segment. On all segments the throw values reach a minimum, although non-zero value near to the fault segment boundaries. It is notable that the peaks within the Turgutlu and Alaşehir segments tend to lie off centre of the strand towards the direction of the Salihli segment in the centre of the array. Throw rates estimated assuming that high-angle faulting has taken place over the last $2 \mathrm{Myr}$, and derived using our total throw constraints, vary from 0.4 to $1.5 \mathrm{~mm} / \mathrm{yr}$ (Fig. 8) at the 20 locations along strike. The throw rates are at a minimum towards the edge of the range with rates lying within the $0.4-0.6 \mathrm{~mm} / \mathrm{yr}$ range. The swath sections located more centrally along the mountain range have higher values three times those found towards the tips of the fault array.

Although, these data represent time-averaged rates across the entire southern margin there is a clear pattern in the throw rates correlating to the position of the GGBF segments. Central swath sections lying on the Salihli fault segment yield throw rates ranging from $\sim 0.7$ to $1.3 \mathrm{~mm} / \mathrm{yr}$. There is a maximum throw rate value within each fault segment of $0.9 \mathrm{~mm} / \mathrm{yr}$ for the Turgutlu Segment, $\sim 1.5 \mathrm{~mm} / \mathrm{yr}$ for the Salihli Segment and $\sim 1.3 \mathrm{~mm} / \mathrm{yr}$ for the Alaşehir Segment.

If we estimate throw rates based on a maximum 2.6 Ma for the timing of fault initiation (e.g. Purvis \& Robertson, 2004; 2005) maximum and minimum throw rates fall to 1.1 and $0.3 \mathrm{~mm} / \mathrm{yr}$, respectively. By contrast, if a young age of $0.7 \mathrm{Ma}$ is used as proposed for the initiation of the GGBF (c.f. Buscher et al., 2013), the maximum and minimum throw rates rise to 4.2 and $1.3 \mathrm{~mm} / \mathrm{yr}$, respectively. However, these higher throw-rates seem 
unrealistic, firstly because the total relief generated by footwall uplift encompasses the activity of all the high-angle faults not just the current (youngest) graben-bounding fault, and secondly, because a throw rate of $>4 \mathrm{~mm} / \mathrm{yr}$ is very high for a normal fault of this size (e.g. Roberts \& Michetti, 2004). The cross-section data (Table 1) do allow for the throw-rate on the frontal part of GGBF to be calculated for the last $0.7 \mathrm{Ma}$ at these locations, the maximum throw was measured on cross-section $\mathrm{C}$ at the base of the Alaşehir Formation and gives a maximum throw rate of $2.4 \mathrm{~mm} / \mathrm{yr}$ for the last $0.7 \mathrm{Ma}$ on the GGBF, assuming that all displacement was accumulated during this time period.

\section{Slip-rate values calculated from the derived throw data}

Displacement values calculated using the Nicol et al. (1997) method range between $\sim 1200 \mathrm{~m}$ and $\sim 4000 \mathrm{~m}$ along strike. The values for each of the 20 locations are documented in table 2 along with calculated slip-rates over the last $2 \mathrm{Ma}$ which range from $0.8 \mathrm{~mm} / \mathrm{yr}$ to $2 \mathrm{~mm} / \mathrm{yr}$. Overall the slip-rates are less in the western extent of the graben margin and higher from the centre to the east, the Turgutlu Segment has an average slip-rate of $0.9 \mathrm{~mm} / \mathrm{yr}$, the Salihli Segment has an average slip-rate of $1.5 \mathrm{~mm} / \mathrm{yr}$ and the Alaşehir Segment was calculated to slip at an average rate of $1.3 \mathrm{~mm} / \mathrm{yr}$.

\section{Discussion}

\section{Along strike trends in the Gediz Graben}

The Gediz Graben boundary fault is $>120 \mathrm{~km}$ long with the longest fault segment of the GGBF being the central Salihli segment at $47 \mathrm{~km}$ in length, the Alaşehir and Turgultu segments are shorter at $42 \mathrm{~km}$ and $35 \mathrm{~km}$ in length, respectively. Fault displacement theory shows that the highest values of throw should be found near the centre of the fault while the throw should reduce to zero at the fault tips (e.g. Barnett et al., 1987; Cowie \& Roberts, 2001; Kim \& Sanderson, 2005).

The centrally-located Salihli segment exhibits the largest throw values of any of the fault segments at ca. $2300-3000 \mathrm{~m}$; the maxima are towards the centre and east of the segment. The smallest values for throw on the Salihli Segment are located at the mapped fault tips, but do not reduce to zero. The maximum throw rate on this central segment is the highest determined for the array at $1.1 \mathrm{~mm} / \mathrm{yr}$.

The Alaşehir Segment has a maximum throw of $2500 \mathrm{~m}$ and there is a peak in the throw rate in the central third of the fault segment of $\sim 1 \mathrm{~mm} / \mathrm{yr}$, similarly to the Salihli 
Segment the minimum values are at the end of the fault segment. There is reduction of throw to zero to the eastern fault tip but the western end of the fault has a non-zero value.

The Turgutlu Segment shows broadly the same trends but with more variation on the throw values along the segment length peaking at $1800 \mathrm{~m}$. There are a series of peaks to the data with a maximum throw-rate value of $0.7 \mathrm{~mm} / \mathrm{yr}$, which lies closer towards the Salihli segment of the fault array. There is a zero value for throw at the western fault tip and a nonzero value for throw at the eastern end of the fault strand near to the western extent of the Salihli segment.

These distributions of throw along strike of the fault segments are in agreement with previous research on fault length and throw scaling (e.g., Cowie \& Roberts, 2001), although there is an absence of zero throw values at the ends of segments where the fault lies next to another segment. It should be noted that the throw derived here is the cumulative throw on all the laterally extensive faults forming the southern margin of the Gediz Graben. We lack the data to isolate the throw variation on the GGBF, although we assume that our results are an acceptable proxy for this. It is also important to note that the peaks in throw rate broadly correspond to the positions of maximum sediment thickness (i.e., subsidence) in the subbasins corresponding to the Alaşehir and Salihli fault segments supporting this analysis (Çifçi \& Bozkurt, 2010).

We have shown that the GGBF is only providing around half of the displacement measured in each location (Fig. 7a), but the total throw value appears to be controlling the relief distribution of the range (Fig. 8). This may suggest that the BFS shared a similar fault segment length and along strike distribution of throw to the GGBF, and so the GGBF is building on an along strike pattern of relief that existed in a similar form prior to the development of the GGBF.

It is well documented that in areas of extension, larger faults form through the linkage of smaller faults in an array (e.g. Dawers \& Anders, 1995; Gawthorpe et al., 1997; Nicol et al., 1997; Cowie, 1998; Peacock, 2002; Roberts \& Michetti 2004) and theory, numerical modelling and field observations suggest that linked faults towards the centre of the array should have higher throw rates than those peripheral in the fault array (e.g. Dawers $\&$ Anders, 1995; Cowie, 1998; Cowie \& Roberts, 2001; Roberts \& Michetti, 2004). The trend in the data for the Gediz Graben across the whole $124 \mathrm{~km}$ fault array is that the highest values for the 2 Ma-averaged throw rate are found towards the centre of the fault array at around 60-75 $\mathrm{km}$ along strike; the highest value of $1.5 \mathrm{~mm} / \mathrm{yr}$ is found $72 \mathrm{~km}$ along strike, within the centre third of the fault array (Fig. 8 b-c). We therefore interpret the distribution of fault throw and 
500

501

502

503

504

505

506

507

508

509

510

511

512

513

514

515

516

517

518

519

520

521

522

523

524

525

526

527

528

529

530

footwall relief along the strike of the Gediz Graben to reflect the interaction and linkage of originally separate fault strands. Linkage of these fault segments is supported by the non-zero throw and throw-rate values at both tips of the central Salihli segment (Fig. 8; Table 2) suggesting the all three fault segments have interacted, causing the Gediz high-angle normal fault array to have grown in steps caused by the linkage events. The position of the throw and throw rate peaks in the Turgutlu and Alaşehir segments, off centre towards the central peak also suggest a shifting on peak throw values along the whole array towards the centre. The fault array also has an along strike bend of approximately $40^{\circ}$ from east to west, which adds additional support for the linkage of the fault segments that bound the modern topographic graben as curvature would result from the linkage of two faults that were not initially parallel.

If the faults in the Gediz Graben are hard-linked it appears that they have not been linked for long as the fault segments still maintain individual peaks while having the central and most significant array throw peak. Research suggests that as faults undergo linkage, the maximum rates of throw on the previously separate faults shift towards the new centre of the linked fault array (Cowie, 1998; Roberts \& Michetti 2004; Kim \& Sanderson, 2005). Mechanically, this type of linkage event leads to increased rate of fault throw, because repeated stress-loading of the centrally-located fault segment(s) occurs, driven by failure of the neighbouring segments located along strike (Cowie, 1998). Moreover, centrally located fault segments are, post-linkage, relatively under-displaced for the larger fault structure that they have become part of (Dawers \& Anders, 1995; Cowie \& Roberts, 2001). As faults become fully linked there would be, over time, a complete convergence of the maximum throw rate to the centre of the new longer fault (Kim \& Sanderson, 2005) likely erasing the evidence of segment peaks over time. Thus these data from the Gediz Graben suggest that the fault segments acted independently before a linkage event that occurred at a time between 2.6 - 2 Ma and the present.

Furthermore, this linkage event may well be what Buscher et al. (2013) have identified as the $\sim 0.7 \mathrm{Ma}$ initiation of the GGBF, as linkage would cause an increase in slip rate due to under displacement of the fault at the linkage site. This increased fault motion and possible block rotation could also potentially result in stratigraphic unconformities such as that observed between the Gediz and Kaletepe formations dated to $\sim 0.8 \mathrm{Ma}$ (e.g. Oner \& Dilek, 2011) 
531

532

533

534

535

536

537

538

539

540

541

542

543

544

545

546

547

548

549

550

551

552

553

554

555

556

557

558

559

560

561

562

563

\section{Regional Comparisons}

Recent GPS studies (Barka \& Reilinger, 1997; Aktug et al., 2009) of the active tectonics of Western Turkey and the Eastern Mediterranean have provided accurate measurement of surface movement over distinct areas depending on the number and locations of GPS stations. The extension within Western Anatolia is taken up largely on E-W and WNW-ESE trending graben systems, including the Gediz Graben, and the major normal faults that bound them, the Gediz, Küthaya and Eskişehir faults. Available GPS data indicate $10 \pm 5 \mathrm{~mm} / \mathrm{yr}$ of extension distributed over the Bozdağ block accommodated by the Gediz and Büyük Menderes grabens (Barka \& Reilinger, 1997).

Aktug et al. (2009) have also produced a study of GPS measurements in westernmost Turkey by dividing the area into polygons of around $10 \mathrm{~km}^{2}$ and calculating velocity gradients assuming a constant gradient within each polygon. They reported an increase in the rate of extension from east to west across the Anatolian Plateau and towards the Aegean coast with the highest magnitude of extension occurring across the Gediz and Büyük Menderes grabens. Strain rates of $140 \times 10^{-9} / \mathrm{yr}$ and $85 \times 10^{-9} / \mathrm{yr}$ have been reported on the Büyük Menderes and Gediz Grabens, respectively, which translates to an opening rate of $6 \mathrm{~mm} / \mathrm{yr}$ for the Büyük Menderes graben and $4 \mathrm{~mm} / \mathrm{yr}$ for the Gediz Graben, agreeing closely with the work of Barka and Reilinger (1997).

The maximum calculated throw-rate on the GGBF for the last $0.7 \mathrm{Ma}$ is $\sim 2.4 \mathrm{~mm} / \mathrm{yr}$ on the Alaşehir segment. Throw rate will be slightly higher on the Salihli segment possibly $2.8 \mathrm{~mm} / \mathrm{yr}$ based upon longer term throw rates. These rates are much higher than the nearby Manisa Fault (Figure 1; forming the westernmost extent of the Gediz Graben system) that has calculated throw rates of $0.1-0.3$ mmyr $^{-1}$ (Özkaymak \& Sözbilir, 2012). Therefore, the GGBF appears to be accommodating $\sim 60-70 \%$ of the predicted deformation across the Gediz Graben at the present day. By contrast, the Manisa Fault appears to be accommodating $<10 \%$ of the regional extension.

\section{Implications for seismic hazard analysis in the Gediz Graben}

Geomorphic and structural evidence from the Gediz Graben demonstrate that faulting is still active with the well-developed modern topographic graben abruptly meeting significant uplift of the graben margin, with recent alluvial fan formation and faceted spurs (Çiftçi, 2007; Oner \& Dilek, 2011). The calculated slip rates also suggest that the high-angle normal faulting has been ongoing for the last $2 \mathrm{Ma}$. Furthermore, the occurrence of large earthquakes such as the 6.9 magnitude Alaşehir earthquake in 1969 indicates that large 
earthquakes do occur along these faults (Arpat \& Bingol, 1969; Eyidoğan \& Jackson, 1985). Furthermore, ${ }^{36} \mathrm{Cl}$ exposure dating on the nearby, $35 \mathrm{~km}$ long, Manisa Fault indicates that this fault also has a history of earthquakes of $\mathrm{M}_{\mathrm{w}}>6$ (Akçar et al., 2012).

Notably, Cowie and Roberts (2001) state that seismic hazard can vary along the length of a fault array based upon the magnitude of fault throw along strike. The implications of this are that in order to provide a useful assessment of seismic hazard complete with spatial variation, a high resolution record of throw rates in a number of locations along strike of the fault array is needed (Roberts \& Michetti, 2004). This study therefore provides the data needed for a higher resolution indication of seismic hazard than has previously been published for the Gediz Graben. Although construction of a detailed seismic hazard map for the Gediz Graben is beyond the scope of this paper, it is possible to calculate the maximum magnitude of an earthquake in the Gediz Graben. One way to estimate the maximum magnitude for a fault is using surface rupture length. Normally between one half and one third of the total length of the fault is thought to rupture in a seismic event (Mark, 1977).

Following Wells and Coppersmith (1994), the moment magnitude (Mw) this can be expressed, for a normal fault, as equation

$$
\mathrm{Mw}=4.86+1.32 \log \mathrm{L}
$$

where $\mathrm{L}$ is fault rupture length (in $\mathrm{km}$ ).

The fault array that bounds the Gediz Graben is linked at two locations along strike with three segments of around $40 \mathrm{~km}$ in length, giving a total length of $120 \mathrm{~km}$. A rupture that occurs along the whole of one of the $40 \mathrm{~km}$ segments would produce an earthquake of predicted magnitude 6.9. If the rupture was to occur over one half to one third of the segment this would produce an earthquake with predicted $\mathrm{Mw}$ of 6.3 to 6.5. As the fault segments have linked it is possible that the fault array could act as one longer fault of $120 \mathrm{~km}$. If the whole of the array were to rupture the predicted $\mathrm{Mw}$ is 7.6. A rupture of one half of the array, $60 \mathrm{~km}$, would produce a predicted $\mathrm{Mw}$ of 7.2. It is also possible that because the Pleistocene to Recent sedimentary units of the Gediz Graben are generally unconsolidated, the effects of an earthquake would be increased in these areas. As many of the main population centres are situated on the sedimentary fill of the graben any earthquake that occurs, even on one third of a fault segment could produce an earthquake of significant magnitude that would have severe implications for a region with a population of at least 400,000. 


\section{Conclusions}

Using a combination of structural cross-sections, stratigraphic data and topographic analyses, this study shows that the total throw on the normal faults ranges from $2000 \mathrm{~m}$ to $3900 \mathrm{~m}$ where the accumulated of throw is approximately equally distributed between the BFS and GGBF. Throw values have three peaks, located at approximately the centre of each of the three fault segment with an overall peak within the centre segment of the fault array. The minimum throw values for all segments are found near to near to the fault segment boundaries. It is notable that the peaks within the Turgutlu and Alaşehir segments tend to lie off centre, although they are non-zero. The distribution of fault throw and footwall relief along the strike reflects the interaction and linkage of originally separate fault strands. The non-zero throw and throw-rate values at both tips of the central Salihli segment suggests all three fault segments have linked and the Gediz high-angle normal fault array has grown in steps caused by the linkage events. Throw rates estimated assuming that high-angle faulting has taken place over the last $2 \mathrm{Myr}$, and derived using our total throw constraints, vary from 0.4 to $1.5 \mathrm{~mm} / \mathrm{yr}$ at the 20 locations along strike. The throw rates are at a minimum towards the edge of the range with rates lying within the $0.4-0.6 \mathrm{~mm} / \mathrm{yr}$ range. The swath sections located more centrally along the mountain range have higher values three times those found towards the tips of the fault array. The throw rates on the GGBF varies from 0.4 to $>1.2$ $\mathrm{mm} / \mathrm{yr}$ along the fault array and this is mirrored by the relief, with the potential of producing an earthquake in the range of $\mathrm{M}_{\mathrm{w}}=6.3-7.6$.

These results are important as they not only provide novel quantification of throw rates of the bounding faults of the southern margin of the Gediz Graben, providing greater insight into the active tectonics of the area, but it also highlights the potential impact to studies of past tectonics of the use of geomorphic data alongside the traditionally used geological data. The key point arising from this study is that currently available geological data on its own does not give much information about the graben tectonics and how they change through time. Yet by combining geologic data with the geomorphic data from topographic studies, new data about the active faulting within the Gediz Graben has been produced and quantified.

\section{Acknowledgements}

This work forms part of EKs PhD research funded by the School of Geography, Earth and Environmental Sciences, Plymouth University. SJB also acknowledges Plymouth University and ACW Imperial College for fieldwork support. 


\section{References}

633

634

635

636

637

638

639

640

641

642

643

644

Akçar, N., Tikhomirov, D., Özkaymak, Ç., Ivy-Ochs, S., Alfimov, V., Sözbilir, H., Uzel, B. \& Schlüchter, C. (2012). $36 \mathrm{Cl}$ exposure dating of paleoearthquakes in the Eastern Mediterranean: First results from the western Anatolian Extensional Province, Manisa fault zone, Turkey. Geological Society of America Bulletin, 124, 1724-1735.

Aktug, B., Nocquet, J. M., Cingöz, A., Parsons, B., Erkan, Y., England, P., Lenk, O., GürdaL, M. A., Kilicoglu, A., Akdeniz, H., \& Tekgül, A. (2009). Deformation of western Turkey from a combination of permanent and campaign GPS data: Limits to block-like behavior. Journal of Geophysical Research: Solid Earth (1978-2012), 114(B10).

Ambraseys, N. N., \& Jackson, J. A. (1998). Faulting associated with historical and recent earthquakes in the Eastern Mediterranean region. Geophysical Journal International, 133(2), 390-406.

Armijo, R., Meyer, B. G. C. P., King, G. C. P., Rigo, A., \& Papanastassiou, D. (1996). Quaternary evolution of the Corinth Rift and its implications for the Late Cenozoic evolution of the Aegean. Geophysical Journal International, 126(1), 11-53.

Arpat, E., \& Bingöl, E. (1969). Ege Bölgesi graben sisteminin gelişimi üzerine düşünceler. MTA Dergisi, 73, 1-8.

Barka, A. \& Reilinger, R. (1997). Active tectonics of the Eastern Mediterranean region: deduced from GPS, neotectonic and seismicity data. Annals of Geophysics, 40(3).

Barnett, J. A., Mortimer, J., Rippon, J. H., Walsh, J. J., \& Watterson, J. (1987). Displacement geometry in the volume containing a single normal fault. AAPG Bulletin, 71(8), 925-937.

Benda, L. 1971. Grundzüge einer pollenanalytischen Gliederung des türkischen Jungtertiärs. Beihefte Zum Geologischen Jahrbuch, 113, 1-46.

Benda, L., Meulenkamp. J.E. (1979) Biostratigraphic correlations in the Eastern Mediterranean Neogene: 5. Calibration of sporomorph associations, marine microfossils and mammal zones, marine and continental stages and the radiometric scale. Annales Géolgiques des Pays Helleniques (hors sér.), 1, 61-70. 
Bozkurt, E., (2000). Timing of extension on the Büyük Menderes Graben, western Turkey, and its tectonic implications, in: E. Bozkurt, J. A.

Winchester, J. D. A. Piper (Eds.), Tectonics and Magmatism in Turkey and the Surrounding Area, 173, Special Publications, Geological Society, London, 2000, pp. 385-403.

Bozkurt, E. (2003). Origin of NE-trending basins in western Turkey. Geodinamica Acta, $16(2), 61-81$.

Bozkurt, E., \& Oberhänsli, R. (2001). Menderes Massif (Western Turkey): structural, metamorphic and magmatic evolution-a synthesis. International Journal of Earth Sciences, 89(4), 679-708.

Bozkurt, E., \& Sözbilir, IR, H. (2004). Tectonic evolution of the Gediz Graben: field evidence for an episodic, two-stage extension in western Turkey. Geological Magazine, 141(01), 63-79.

Buscher, J. T., Hampel, A., Hetzel, R., Dunkl, I., Glotzbach, C., Struffert, A., ... \& Rätz, M. (2013). Quantifying rates of detachment faulting and erosion in the central Menderes Massif (western Turkey) by thermochronology and cosmogenic 10Be. Journal of the Geological Society, 170(4), 669-683.

Çemen, I., Catlos, E. J., Gögüs, O., \& Özerdem, C. (2006). Postcollisional extensional tectonics and exhumation of the Menderes massif in the Western Anatolia extended terrane, Turkey. Geological Society of America Special Papers, 409, 353-379.

Çiftçi., N. B. (2007). Geological evolution of the Gediz graben, SW Turkey: Temporal and spatial variation of the graben. Ph. D. thesis, Middle East Technical University, Ankara, Turkey.

Çiftçi, N. B. \& Bozkurt, E. (2007) Anomalous stress field and active breaching at relay ramps: a field example from Gediz Graben, SW Turkey. Geological Magazine, 144, 687699.

Çiftçi, N. B., \& Bozkurt, E. (2009a). Pattern of normal faulting in the Gediz Graben, SW Turkey. Tectonophysics, 473(1), 234-260.

Çiftçi, N. B., \& Bozkurt, E. (2009b). Evolution of the Miocene sedimentary fill of the Gediz Graben, SW Turkey. Sedimentary Geology, 216(3), 49-79. 
688

689

690

691

692

693

694

695

696

697

698

699

700

701

702

703

704

705

706

707

708

709

710

711

712

713

714

Çiftçi, N. B. \& Bozkurt, E. (2010) Structural evolution of the Gediz graben, SW Turkey: Temporal and spatial variation of the graben basin: Basin Research, 22, 846-873.

Collins, A. S., \& Robertson, A. H. (2003). Kinematic evidence for late Mesozoic-Miocene emplacement of the Lycian Allochthon over the western Anatolide belt, SW Turkey. Geological Journal, 38(3-4), 295-310.

Cohen, H. A., Dart, C. J., Akyüz, H. S., \& Barka, A. (1995). Syn-rift sedimentation and structural development of the Gediz and Büyük Menderes graben, western Turkey. Journal of the Geological Society, 152(4), 629-638.

Coppersmith, K. J., \& Youngs, R. R. (1989). Issues regarding earthquake source characterization and seismic hazard analysis within passive margins and stable continental interiors. In Earthquakes at North-Atlantic Passive Margins: Neotectonics and Postglacial Rebound (pp. 601-631). Springer Netherlands.

Cowie, P. A. (1998). A healing-reloading feedback control on the growth rate of seismogenic faults. Journal of Structural Geology, 20(8), 1075-1087.

Cowie, P. A., \& Roberts, G. P. (2001). Constraining slip rates and spacings for active normal faults. Journal of Structural Geology, 23(12), 1901-1915.

Dawers, N. H., \& Anders, M. H. (1995). Displacement-length scaling and fault linkage. Journal of Structural Geology, 17(5), 607-614.

Demircioğlu, D., Ecevitoğlu, B., \& Seyitoğlu, G. (2010). Evidence of a rolling hinge mechanism in the seismic records of the hydrocarbon-bearing Alaşehir graben, western Turkey. Petroleum Geoscience, 16(2), 155-160.

Dewey, J. F. (1988). Extensional collapse of orogens. Tectonics, 7(6), 1123-1139.

Ediger, V., Bati, Z. \& Yazman, M., (1996). Palynology of possible hydrocarbon source rocks of the Alasehir-Turgutlu area in the Gediz graben (western Anatolia). Turkish Association of Petroleum Geologists Bulletin 8, 94-112.

Emre, T. (1996). The tectonic evolution of the Gediz graben. Geological Bulletin of Turkey, $39,1-18$. 
Erdoğan, O (2014). On the History of Religions in Philadelphia in Lydia until the end of Late Antiquity. Mediterranean Journal of Humanities, IV/I, 171-179.

Eyidoğan, H., \& Jackson, J. (1985). A seismological study of normal faulting in the Demirci, Alaşehir and Gediz earthquakes of 1969-70 in western Turkey: implications for the nature and geometry of deformation in the continental crust. Geophysical Journal International, 81(3), 569-607.

Gawthorpe, R. L., Sharp, I., Underhill, J. R., \& Gupta, S. (1997). Linked sequence stratigraphic and structural evolution of propagating normal faults. Geology, 25(9), 795798.

Hetzel, R., Passchier, C. W., Ring, U., \& Dora, Ö. O. (1995). Bivergent extension in orogenic belts: the Menderes massif (southwestern Turkey). Geology, 23(5), 455-458.

Işik, Seyitoğlu, G., Çemen, I., (2003). Ductile-brittle transition along the Alaşehir shear zone and its structural relationship with the Simav detachment, Menderes Massif, western Turkey. Tectonophysics, 374, 1-18.

Iztan, H. \& Yazman M. (1991). Geology and hydrocarbon potential of the Alaşehir (Manisa) area, western Turkey. Proceedings of the International Earth Sciences Congress on Aegean Regions, 327-338.

Kim, Y. S., \& Sanderson, D. J. (2005). The relationship between displacement and length of faults: a review. Earth-Science Reviews, 68(3), 317-334.

Kissel, C., \& Laj, C. (1988). The Tertiary geodynamical evolution of the Aegean arc: a paleomagnetic reconstruction. Tectonophysics, 146(1), 183-201.

Koçyigit, A., Yusufoglu, H., \& Bozkurt, E. (1999). Discussion on evidence from the Gediz Graben for episodic two-stage extension in western Turkey. Journal of the Geological Society, London, 156, 1240-1242.

Le Pichon, X., Angelier, J., (1979). The Hellenic arc and trench system: a key to the neotectonic evolution of the eastern Mediterranean Sea. Tectonophysics, 60, 1-42.

Lips, A. L., Cassard, D., Sözbilir, H., Yilmaz, H., \& Wijbrans, J. R. (2001). Multistage exhumation of the Menderes massif, western Anatolia (Turkey). International Journal of Earth Sciences, 89(4), 781-792. 
Mark, R. K. (1977). Application of linear statistical models of earthquake magnitude versus fault length in estimating maximum expectable earthquakes. Geology, 5(8), 464-466.

Meulenkamp, J. E., Wortel, M. J. R., Van Wamel, W. A., Spakman, W., \& Strating, E. H. (1988). On the Hellenic subduction zone and the geodynamic evolution of Crete since the late Middle Miocene. Tectonophysics, 146(1), 203-215.

Meulenkamp, J. E., Van der Zwaan, G. J., \& Van Wamel, W. A. (1994). On Late Miocene to recent vertical motions in the Cretan segment of the Hellenic arc. Tectonophysics, 234(1), 53-72.

NASA Land Processes Distributed Active Archive Center (2001). ASTER L1B DEM. USGS/Earth Resources Observation and Science (EROS) Center, Sioux Falls, South Dakota.

Nicol, A., Walsh, J. J., Watterson, J., \& Underhill, J. R. (1997). Displacement rates of normal faults. Nature, 390(6656), 157-159.

Oner, Z., \& Dilek, Y. (2011). Supradetachment basin evolution during continental extension: The Aegean province of western Anatolia, Turkey. Geological Society of America Bulletin, 123(11-12), 2115-2141.Papanikolaou, I. D., Foumelis, M., Parcharidis, I., Lekkas, E. L., \& Fountoulis, I. G. (2010). Deformation pattern of the 6 and 7 April 2009, $\mathrm{MW}=6.3$ and $\mathrm{MW}=5.6$ earthquakes in L'Aquila (Central Italy) revealed by ground and space based observations. Natural Hazards and Earth System Sciences, 10, 73-87.

Özkaymak, Ç., \& Sözbilir, H. (2012). Tectonic geomorphology of the Spildağı high ranges, western Anatolia. Geomorphology, 173, 128-140.

Patton, S. 1992. Active normal faulting, drainage patterns and sedimentation in southwestern Turkey. Journal of the Geological Society, London, 149, 1031-1044.

Peacock, D. C. P. (2002). Propagation, interaction and linkage in normal fault systems. EarthScience Reviews, 58(1), 121-142.

Purvis, M., \& Robertson, A. (2004). A pulsed extension model for the Neogene-Recent E-Wtrending Alaşehir Graben and the NE-SW-trending Selendi and Gördes Basins, western Turkey. Tectonophysics, 391(1), 171-201. 
Purvis, M., \& Robertson, A. (2005). Sedimentation of the Neogene-Recent Alaşehir (Gediz) continental graben system used to test alternative tectonic models for western (Aegean) Turkey. Sedimentary Geology, 173(1), 373-408.

Richardson-Bunbury, J. M. (1996). The Kula volcanic field, western Turkey: the development of a Holocene alkali basalt province and the adjacent normal-faulting graben. Geological Magazine, 133(03), 275-283.

Ring, U., Johnson, C., Hetzel, R., \& Gessner, K. (2003). Tectonic denudation of a Late Cretaceous-Tertiary collisional belt: regionally symmetric cooling patterns and their relation to extensional faults in the Anatolide belt of western Turkey. Geological Magazine, 140(04), 421-441.

Roberts, G. P., \& Michetti, A. M. (2004). Spatial and temporal variations in growth rates along active normal fault systems: an example from The Lazio-Abruzzo Apennines, central Italy. Journal of Structural Geology, 26(2), 339-376.

Roberts, G. P., Cowie, P., Papanikolaou, I., \& Michetti, A. M. (2004). Fault scaling relationships, deformation rates and seismic hazards: an example from the Lazio-Abruzzo Apennines, central Italy. Journal of Structural Geology, 26(2), 377-398.

Şan O. (1998) Ahmetli (Manisa) guneyinde Menderes masifi ve Tersiyer ortu kayalarinin jeolojisi [Geology of the basement and Tertiary cover rocks of Menderes massif in the south of Ahmetli (Manisa)] MSc thesis (Ankara University).

Sarica, N. (2000). The Plio-Pleistocene age of Buyuk Menderes and Gediz grabens and their tectonic significance on N-S extensional tectonics in West Anatolia: mammalian evidence from the continental deposits. Geological Journal, 35(1), 1-24.

Saunders, P., Priestley, K., \& Taymaz, T. (1998). Variations in the crustal structure beneath western Turkey. Geophysical Journal International, 134(2), 373-389.

Sen, S., \& Seyitoğlu, G. (2009). Magnetostratigraphy of early-middle Miocene deposits from east-west trending Alaşehir and Büyük Menderes grabens in western Turkey, and its tectonic implications. Geological Society, London, Special Publications, 311(1), 321-342. 
801

802

803

804

805

806

807

808

809

810

811

812

813

814

815

816

817

818

819

820

821

822

823

824

825

826

827

Şengör, A. M. C. (1987). Cross-faults and differential stretching of hanging walls in regions of low-angle normal faulting: examples from western Turkey. Geological Society, London, Special Publications, 28(1), 575-589.

Sengör, A. M. C., Satir, M., \& Akkök, R. (1984). Timing of tectonic events in the Menderes Massif, western Turkey: Implications for tectonic evolution and evidence for Pan-African basement in Turkey. Tectonics, 3(7), 693-707.Seyitoğlu, G. \& Benda, L. 1998. Neogene palynological and isotopic age data from Selendi and Usak-Güre basins, western Turkey: A contribution to the upper limit of Eskihisar sporomorph association. Newsletters on Stratigraphy, 36, 105-115.

Seyitoğlu, G., \& Scott, B. C. (1996). Age of the Alaşehir graben (west Turkey) and its tectonic implications. Geological Journal, 31(1), 1-11.

Seyitoğlu, G., Tekeli, O., Çemen, I., Sen, S., \& Işik, V. (2002). The role of the flexural rotation/rolling hinge model in the tectonic evolution of the Alasehir graben, western Turkey. Geological Magazine, 139(01), 15-26.

Seyitoğlu, G., Veysel, I. Ş. I. K., \& Korhan, E. S. A. T. (2014). A 3D model for the formation of turtleback surfaces: the Horzum Turtleback of western Turkey as a case study. Turkish Journal of Earth Sciences, 23(5), 479-494.

Sözbilir, H. (2001). Extensional tectonics and the geometry of related macroscopic structures: field evidence from the Gediz detachment, western Turkey. Turkish Journal of Earth Sciences, 10(2), 51-67.

Sözbilir, H. (2002). Geometry and origin of folding in the Neogene sediments of the Gediz Graben, western Anatolia, Turkey. Geodinamica Acta, 15(5-6), 277-288.

Stein, R.S. Barrientos S.E., (1985). Planar high-angle faulting in the Basin and Range; geodetic analysis of the 1983 Borah Peak, Idaho, earthquake. Journal of Geophysical Research, 90, 11,355-11,366.

Emre, T. (1996). Geology and the Tectonics of the Gediz Graben. Turkish Journal of Earth Sciences, 5(3), 171-185 
ten Veen, J.H., Boulton, S.J. and Alçiçek, M.C., 2009. Ocean closure, post-orogenic collapse and neotectonics in the Neotethys realm: the importance of kinematic decoupling and inherited structural grain in S.W. Anatolia (Turkey). Tectonophysics, 473, 261-281.

Wells, D. L., \& Coppersmith, K. J. (1994). New empirical relationships among magnitude, rupture length, rupture width, rupture area, and surface displacement. Bulletin of the Seismological Society of America, 84(4), 974-1002.

Willgoose, G., Bras, R. L., \& Rodriguez-Iturbe, I. (1991). A physical explanation of an observed link area-slope relationship. Water Resources Research, 27(7), 1697-1702.

Whittaker, A. C., \& Boulton, S. J. (2012). Tectonic and climatic controls on knickpoint retreat rates and landscape response times. Journal of Geophysical Research: Earth Surface, 117(F2).

Whittaker, A. C., \& Walker, A. S. (2015). Geomorphic constraints on fault throw rates and linkage times: Examples from the Northern Gulf of Evia, Greece. Journal of Geophysical Research: Earth Surface. Doi: 10.1002/2014JF003318

Yilmaz, Y., Genç, Ş. C., Gürer, F., Bozcu, M., Yilmaz, K., Karacik, Z., \& Elmas, A. (2000). When did the western Anatolian grabens begin to develop? Geological Society, London, Special Publications, 173(1), 353-384.

\section{Figures}

Figure 1. Simplified geological map of the Western Anatolian Extensional Province (adapted from Bozkurt, 2002; 2003; Seyitoğlu et al., 2004; Çemen et al., 2006), the box shows the location of figures 2 and 4. M - Manisa Fault; GG - Gediz Graben; KMG - Küçük Menderes Graben; BMG -Büyük Menderes Graben; DKBF - Datça-Kale Breakaway Fault (Seyitoğlu et al., 2004), also known as the South West Anatolian Shear Zone (Çemen et al., 2006). Key towns are A - Alaşehir, S- Sahlili, and I - Izmir. 
860

861

862

863

864

865

866

867

868

869

870

871

872

873

874

875

876

877

878

879

880

881

882

883

884

885

886

887

888

889

890

891

892

893

Figure 2. Simplified geological map of the southern margin of the Gediz Graben, modified from Yilmaz et al., (2000); Purvis \& Robertson (2005), Çiftçi \& Bozkurt (2010) and Oner \& Dilek (2011). Inset shows location of seismic lines and boreholes described by Çiftçi (2007).

Figure 3. Comparison of previous stratigraphic frameworks published for the Gediz Graben including evidence for the age of different stratigraphic units, modified from Şen \& Seyitoğlu (2009), Demircioğlu et al. (2010) and Oner \& Dilek (2011).

Figure 4. ASTER Digital elevation model (NASA, 2001) of the Gediz Graben showing the main faults based upon our observations and modified from Yilmaz et al. (2000); Purvis \& Robertson (2005), Çiftçi \& Bozkurt (2010), and Oner \& Dilek, (2011). The locations of cross-sections a - e (dashed lines) shown in Figure 5 and the areas used in the swath profile analysis (boxes) are also indicated.

Figure $5 \mathrm{~A}-\mathrm{F}$. Cross-sections constructed using published and field-checked structural information from Çiftçi \& Bozkurt (2010) and Oner \& Dilek (2011) and sub-surface seismic from Çiftçi (2007). Stars indicate the piercing points used to determine throw and displacement on the BFS and GGBF. The location of each cross-section is shown in figure 4.

Figure 6. Schematic diagram showing the parameters used in determining the along strike relief.

Figure 7. A. Graph showing the measured throw for the GGBF and total throw across the southern graben margin for each cross-section. B. Graph showing the relationship between throw and footwall relief for the GGBF and cumulative throw. GGBF $y=0.23 x+346, \mathrm{R} 2=$ 0.90 ; cumulative $\mathrm{y}=0.15 \mathrm{x}+325, \mathrm{R} 2=0.89$.

Figure 8. A) Graph showing the measured footwall relief along the strike of the southern margin of the Gediz Graben; B) Calculated cumulative throw along the southern margin of the Gediz Graben using the range relief shown in A combined with the calculated average footwall uplift to hangingwall ratio of the graben; C) Calculated throw-rate for the last $2 \mathrm{Ma}$ along strike of the southern margin of the Gediz Graben. On each graph the extent of each major segment of the GGBF is shown for reference. 
Kent et al., Active tectonics of the Gediz Graben

894 Table 1. Throw data derived from the cross-sections shown in figure 5.

895 


\begin{tabular}{|c|c|c|c|c|c|c|c|c|c|c|c|c|}
\hline \multirow[b]{2}{*}{$\begin{array}{l}\text { Cross- } \\
\text { section }\end{array}$} & \multirow{2}{*}{$\begin{array}{l}\text { outer } \\
\text { fault }\end{array}$} & \multicolumn{2}{|c|}{ error } & \multirow{2}{*}{$\begin{array}{l}\text { MGBF } \\
\text { throw } \\
(\mathrm{m})\end{array}$} & \multicolumn{2}{|c|}{ error } & \multirow{2}{*}{$\begin{array}{c}\text { total } \\
\text { throw } \\
\text { (m) }\end{array}$} & \multicolumn{2}{|c|}{ error } & \multirow{2}{*}{$\begin{array}{l}\text { footwall } \\
\text { from } \\
\text { swath }\end{array}$} & \multirow{2}{*}{$\begin{array}{c}\text { FW:TOTAL } \\
\text { THROW } \\
\text { RATIO }\end{array}$} & \multirow{2}{*}{$\begin{array}{l}\text { FW : } \\
\text { HW } \\
\text { RATIO }\end{array}$} \\
\hline & & - & + & & - & + & & - & + & & & \\
\hline a & 950 & 200 & 150 & 700 & 50 & 75 & 1650 & 250 & 225 & 541 & 3.0 & 2.0 \\
\hline$b$ & 1400 & 75 & 100 & 1250 & 50 & 80 & 2650 & 125 & 180 & 618 & 4.3 & 3.3 \\
\hline c & 1800 & 100 & 75 & 1650 & 25 & 50 & 3450 & 125 & 125 & 724 & 4.8 & 3.8 \\
\hline$d$ & 1250 & 200 & 100 & 1200 & 50 & 75 & 2450 & 250 & 175 & 646 & 3.8 & 2.8 \\
\hline e & 1000 & 150 & 50 & 800 & 50 & 50 & 1800 & 200 & 100 & 487 & 3.7 & 2.7 \\
\hline \multirow[t]{2}{*}{. } & 1800 & 50 & 150 & 1500 & 50 & 100 & 3300 & 100 & 250 & 694 & 4.8 & 3.8 \\
\hline & & & & & & & & & & average & 4.1 & 3.1 \\
\hline
\end{tabular}




\begin{tabular}{|c|c|c|c|c|c|c|c|c|c|c|}
\hline $\begin{array}{c}\text { Fault } \\
\text { segment }\end{array}$ & $\begin{array}{c}\text { Swath } \\
\text { no. }\end{array}$ & $\begin{array}{l}\text { Cross- } \\
\text { section }\end{array}$ & $\begin{array}{l}\text { Distance } \\
\text { along } \\
\text { strike } \\
(\mathrm{km})\end{array}$ & $\begin{array}{l}\text { Footwall } \\
\text { relief } \\
\text { (m) }\end{array}$ & $\begin{array}{c}\text { Cumulative } \\
\text { throw }(\mathrm{m}) \\
\text { using } 1: 4.1 \\
\text { ratio }\end{array}$ & $\begin{array}{l}\text { Throw } \\
\text { Rate } \\
\mathrm{mm} / \mathrm{yr} \\
\text { using } \\
2.6 \mathrm{Ma} \\
\end{array}$ & $\begin{array}{l}\text { Throw } \\
\text { Rate } \\
\mathrm{mm} / \mathrm{yr} \\
\text { using } \\
2 \mathrm{Ma} \\
\end{array}$ & $\begin{array}{l}\text { Throw } \\
\text { Rate } \\
\mathrm{mm} / \mathrm{yr} \\
\text { using } \\
0.7 \mathrm{Ma} \\
\end{array}$ & $\begin{array}{l}\text { Displacement } \\
(\mathrm{m})\end{array}$ & $\begin{array}{c}\text { Slip - rate } \\
\text { (over 2ma) } \\
\text { mm/yr }\end{array}$ \\
\hline & 1 & & 3.4 & 295 & 1210 & 0.47 & 0.60 & 1.73 & 1613 & 0.81 \\
\hline & 2 & & 8.7 & 342 & 1402 & 0.54 & 0.70 & 2.00 & 1870 & 0.93 \\
\hline & 3 & & 14.5 & 290 & 1189 & 0.46 & 0.59 & 1.70 & 1585 & 0.79 \\
\hline \multirow[t]{8}{*}{ Turgutlu } & 4 & & 19.7 & 398 & 1632 & 0.63 & 0.82 & 2.33 & 2176 & 1.09 \\
\hline & 5 & & 24.7 & 348 & 1427 & 0.55 & 0.71 & 2.04 & 1902 & 0.95 \\
\hline & 6 & & 29.8 & 437 & 1792 & 0.69 & 0.90 & 2.56 & 2389 & 1.19 \\
\hline & 7 & & 35.3 & 217 & 890 & 0.34 & 0.44 & 1.27 & 1186 & 0.59 \\
\hline & 8 & & 40.4 & 354 & 1451 & 0.56 & 0.73 & 2.07 & 1935 & 0.97 \\
\hline & 9 & & 45.7 & 424 & 1738 & 0.67 & 0.87 & 2.48 & 2318 & 1.16 \\
\hline & 10 & & 50.3 & 483 & 1980 & 0.76 & 0.99 & 2.83 & 2640 & 1.32 \\
\hline & 11 & & 55.6 & 625 & 2563 & 0.99 & 1.28 & 3.66 & 3417 & 1.71 \\
\hline \multirow[t]{6}{*}{ Salihli } & 12 & $\mathrm{~F}$ & 60.3 & 694 & 2845 & 1.09 & 1.42 & 4.06 & 3794 & 1.90 \\
\hline & 13 & D & 65.3 & 646 & 2649 & 1.02 & 1.32 & 3.78 & 3531 & 1.77 \\
\hline & 14 & C & 70.3 & 724 & 2968 & 1.14 & 1.48 & 4.24 & 3958 & 1.98 \\
\hline & 15 & & 75.4 & 618 & 2534 & 0.97 & 1.27 & 3.62 & 3378 & 1.69 \\
\hline & 16 & E & 81.2 & 487 & 1997 & 0.77 & 1.00 & 2.85 & 2662 & 1.33 \\
\hline & 17 & & 86.3 & 472 & 1935 & 0.74 & 0.97 & 2.76 & 2580 & 1.29 \\
\hline \multirow[t]{3}{*}{ Alaşehir } & 18 & B & 91.9 & 618 & 2534 & 0.97 & 1.27 & 3.62 & 3378 & 1.69 \\
\hline & 19 & A & 100 & 541 & 2218 & 0.85 & 1.11 & 3.17 & 2957 & 1.48 \\
\hline & 20 & & 110 & 290 & 1189 & 0.46 & 0.59 & 1.70 & 1585 & 0.79 \\
\hline
\end{tabular}


2

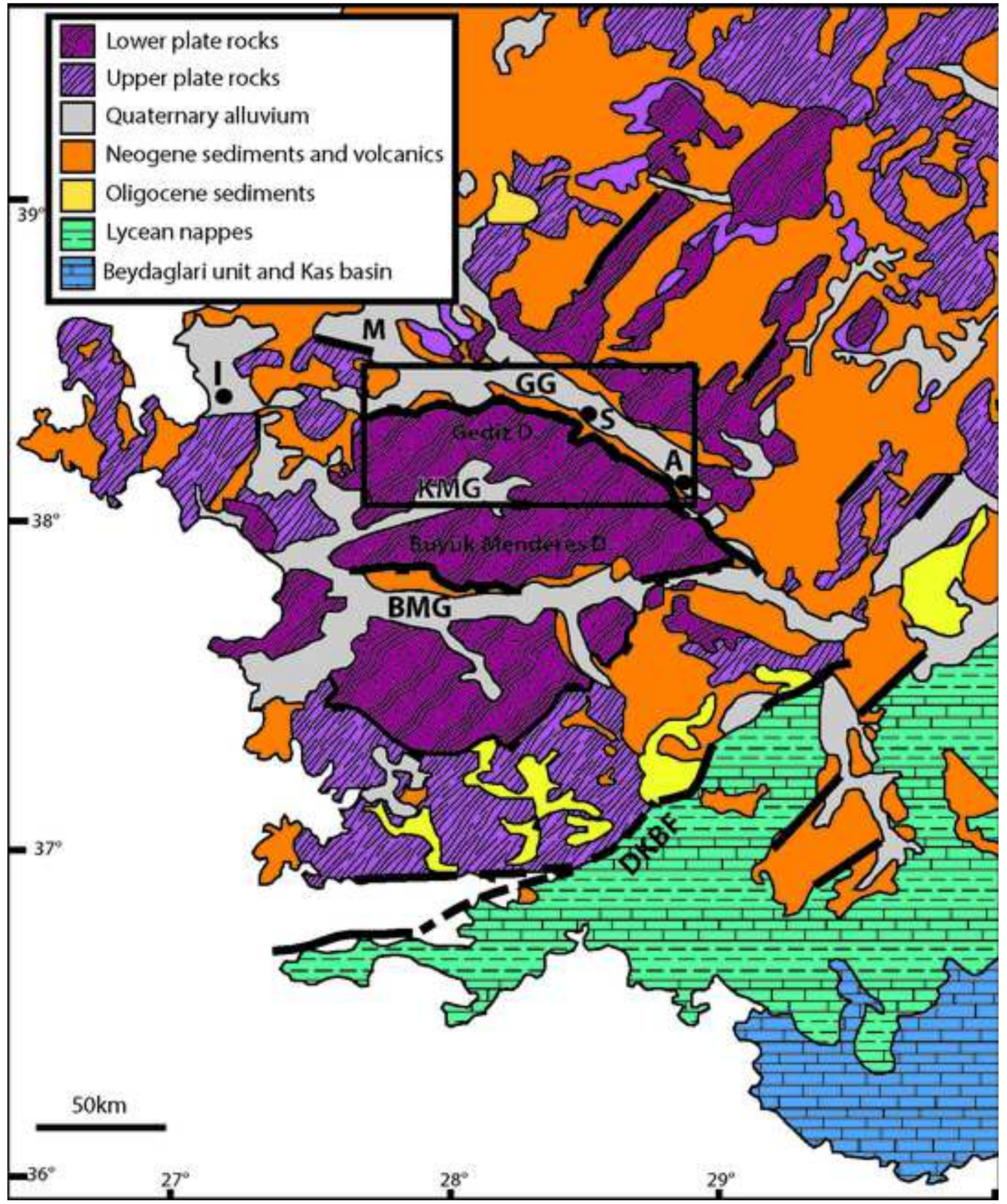




\section{D}

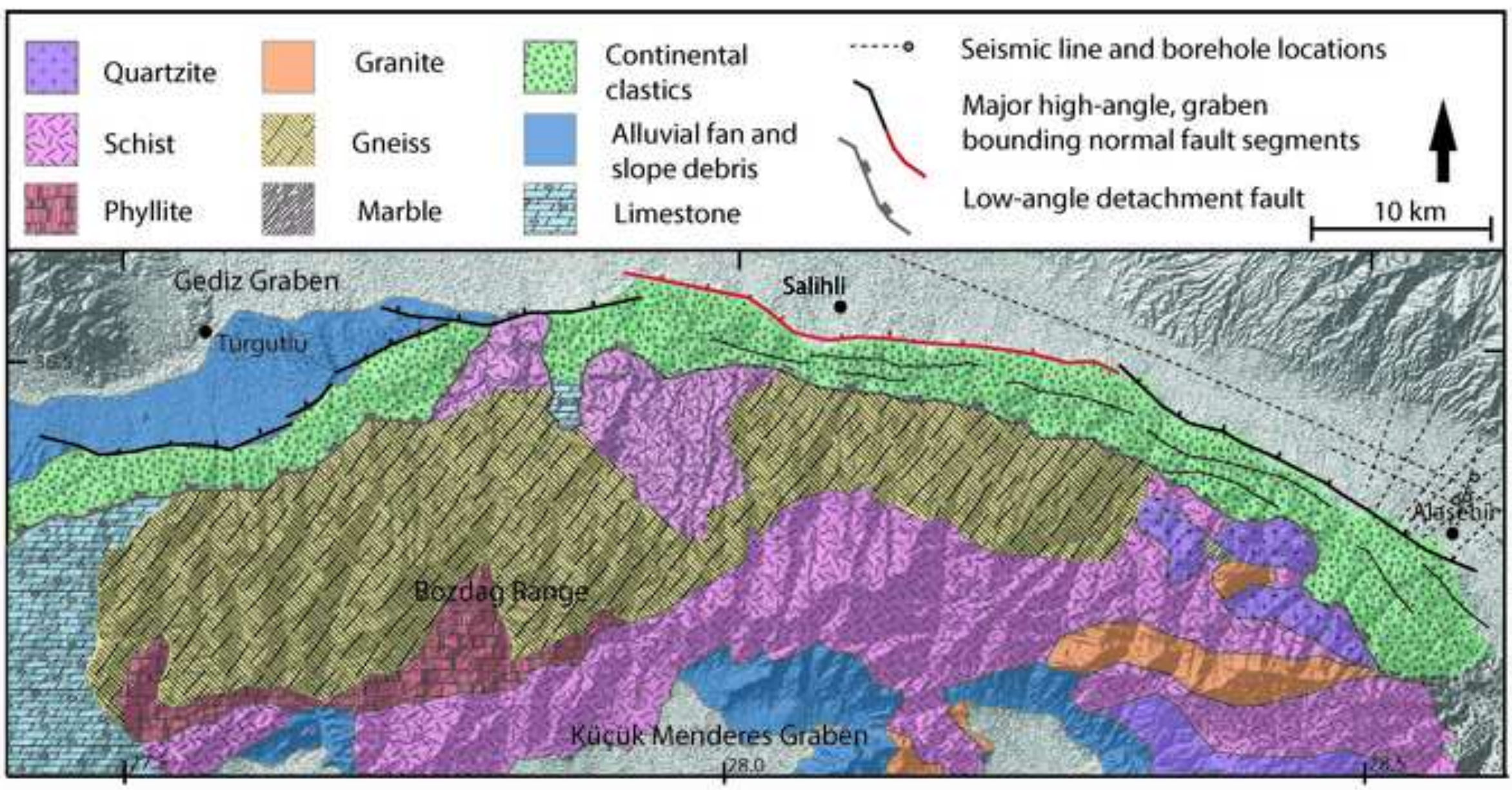




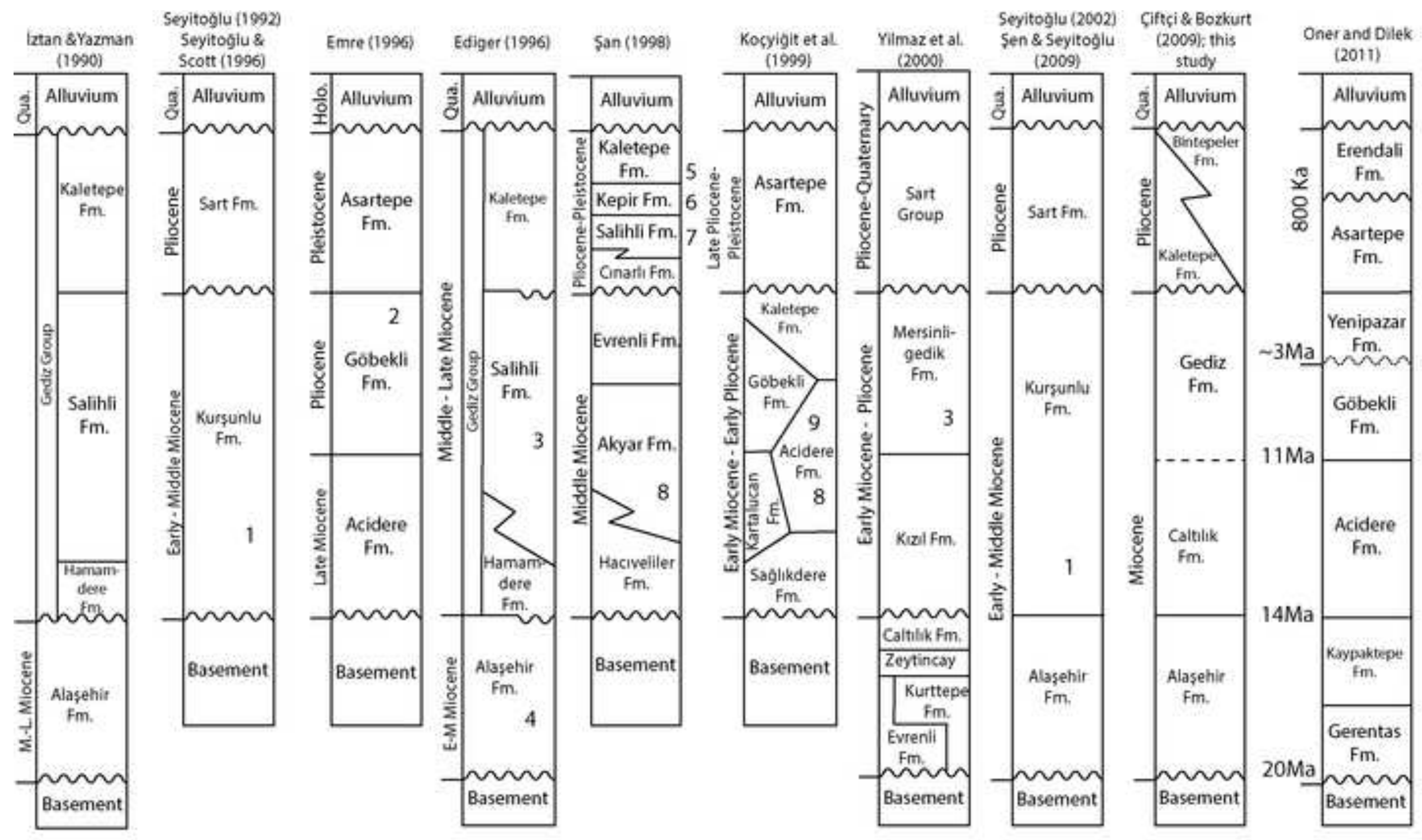

1 Eskihisar sporomorph association, Seyitoğlu \& Scott (1996)

2 Gastropoda, Emre (1996)

3 Yeni Eskihisar, Kizihisar sporomorph association, Ediger et al. (1996)

4 Eskihisar sporomorph association, Ediger et al. (1996)
S Gastropoda, Şan (1998)

6 Mimomys ct. pliocoenicus, \$an (1998)

7 Microtus sp. \$an (1998)

8 Crocodylia sp. San (1998) 


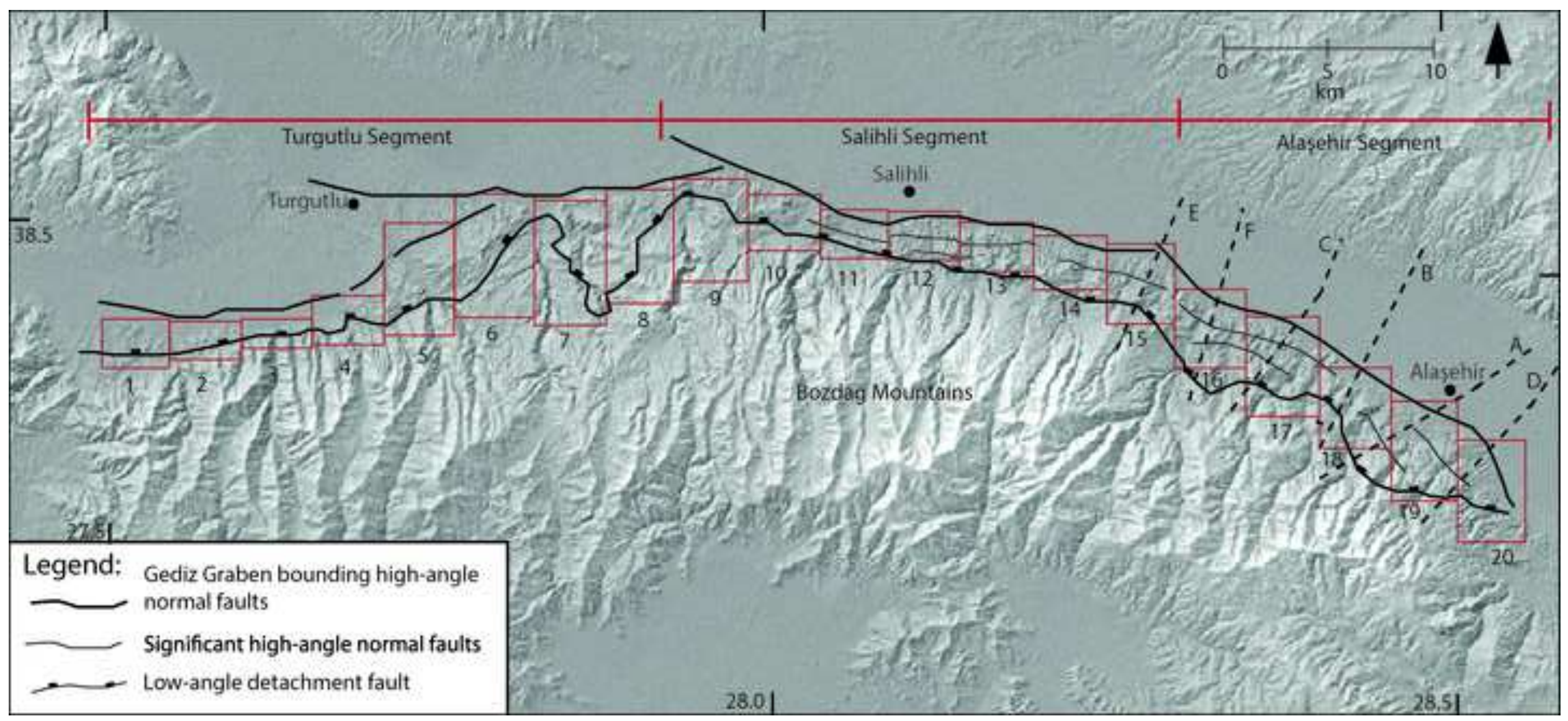



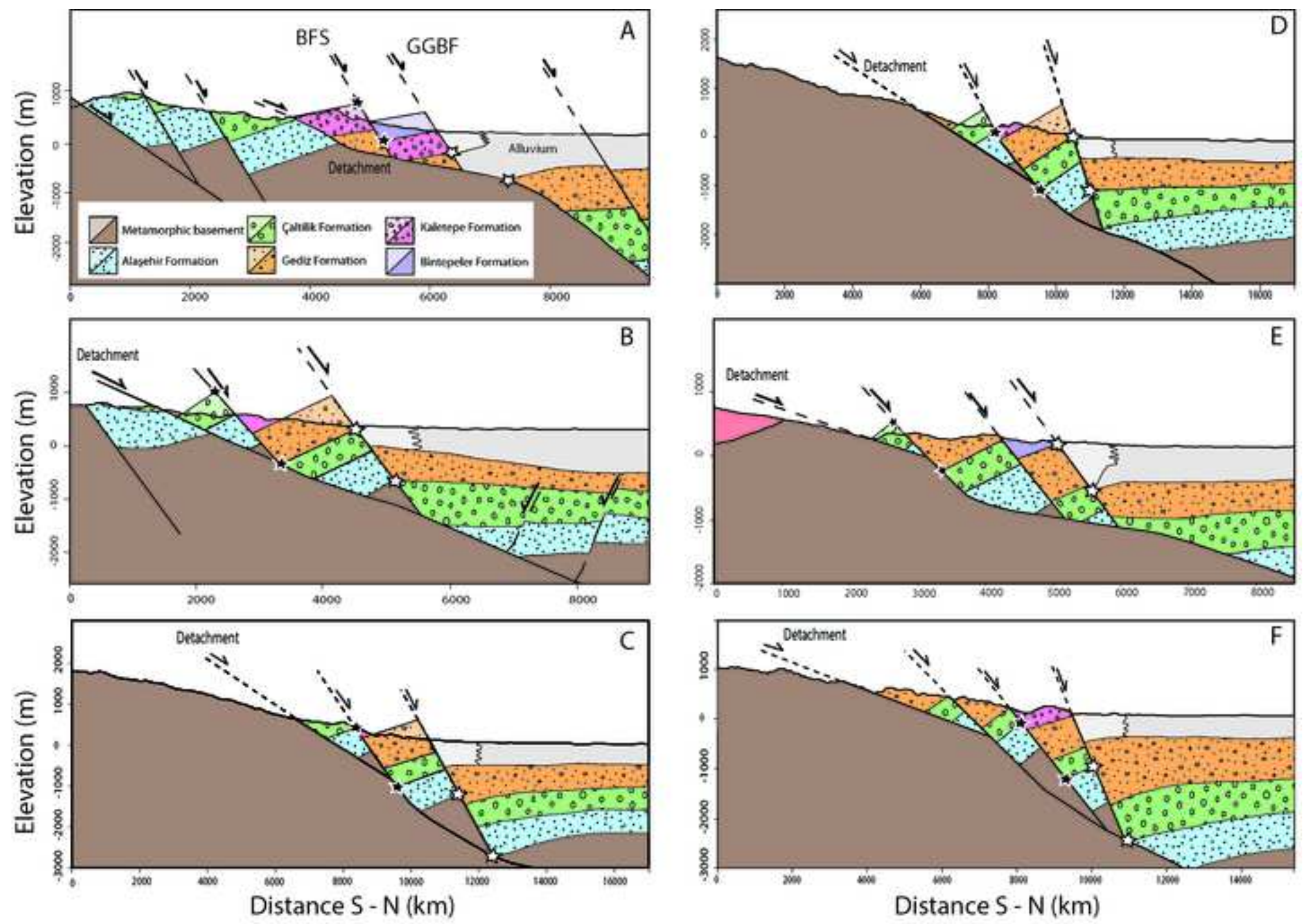


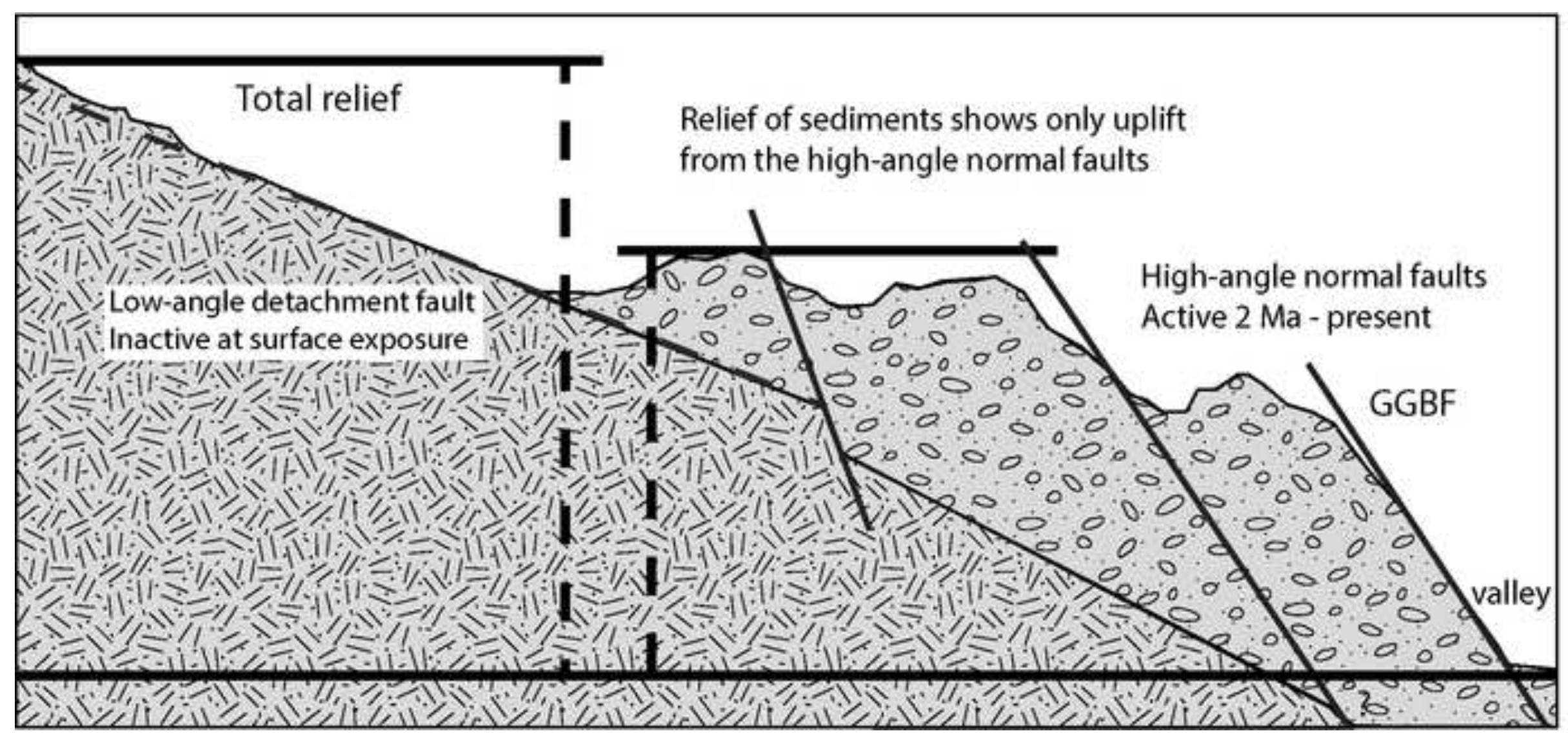



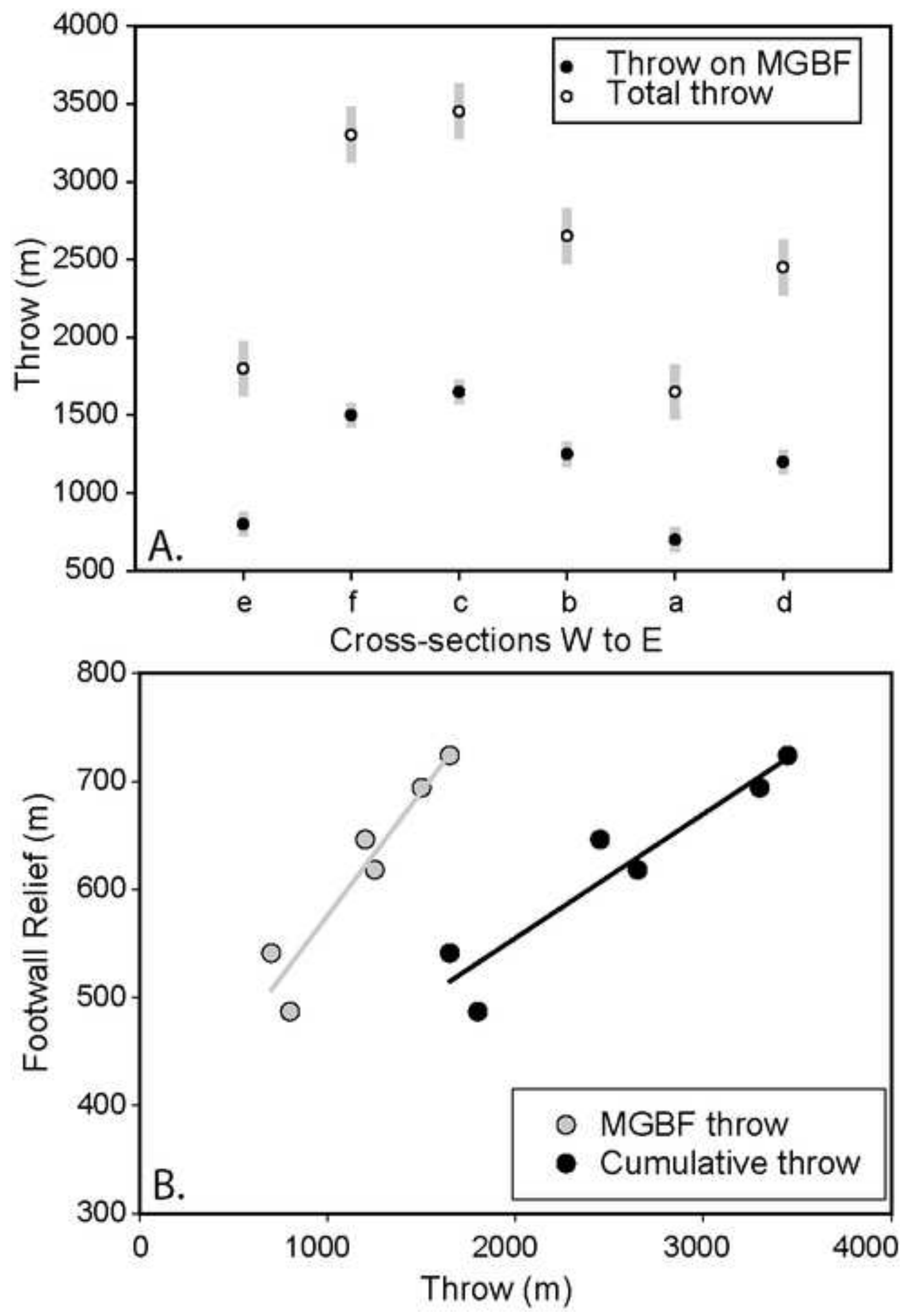

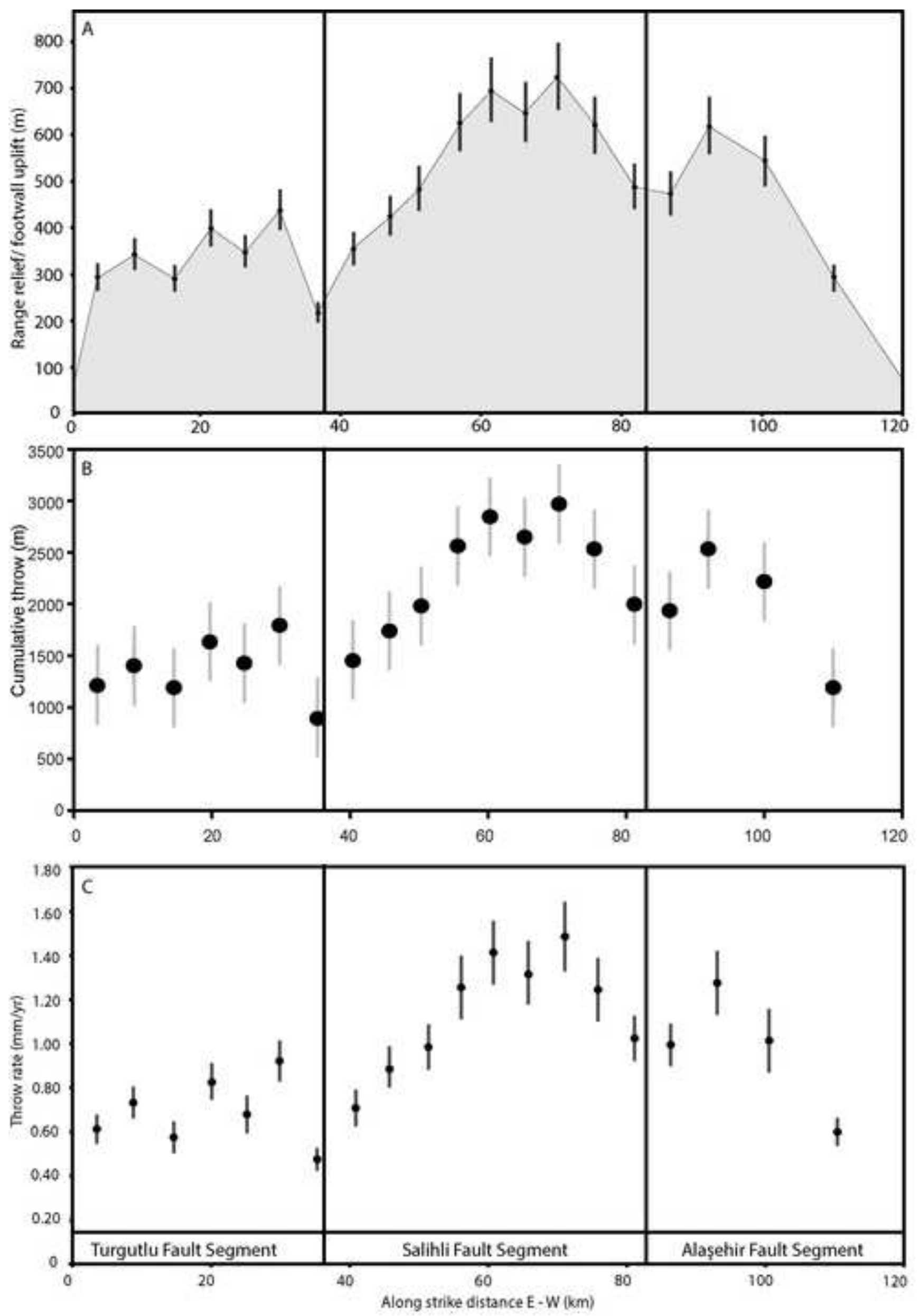